\title{
THE HISTORY OF THE \\ Organized PSEudolegal CoMmercial Argument Phenomenon In CANAdA
}

\author{
DONALD J. NETOLITZKY*
}

\begin{abstract}
This article discusses the history of the poorly understood Organized Pseudolegal Commercial Arguments (OPCA) phenomena. Drawing from various reported and unreported sources, the author begins his review in the 1950s with two distinct pseudolegal traditions that evolved separately in both the United States and Canada. Focusing on the prominent members of each era of the OPCA movement, the author explains in depth the concepts behind the movement and what it means for the legal system in Canada today. The article culminates with an analysis of the current OPCA groups and how Canadian courts should respond to future OPCA litigants, while also giving reasons as to why it is important for Canadians to take notice of this movement due to potential security risks.
\end{abstract}

\section{TABLE OF CONTENTS}

I. INTRODUCTION . . . . . . . . . . . . . . . . . . . . 610

II. Two SePArate PseUdolegal Traditions $\ldots \ldots \ldots \ldots \ldots \ldots \ldots \ldots 613$

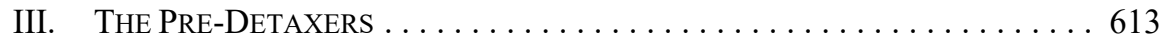

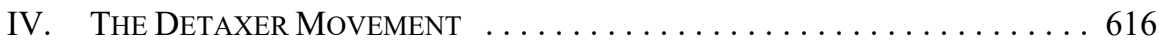

A. The US Influence: Warman, Kyburz, MulJiAni . . . . . . . . 617

B. The Pre-DetaXers' SuCCESSORS: ButTERFIELD,

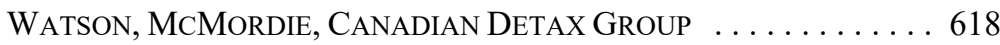

C. The Detaxer Scholar: David KeVin LindSAY . . . . . . . . . . 620

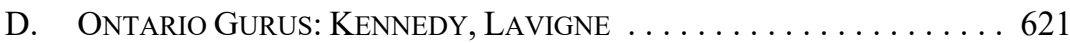

E. ABORIGINAL DETAXER: Agecoutay, A.K.A. King KaneEKaneEt . . . . . . . . . . 622

F. THE NATURAL PERSON: PORISKY AND THE PARADIGM EDUCATION GROUP . . . . . . . . . . . . . 622

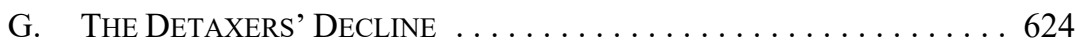

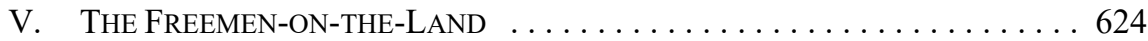

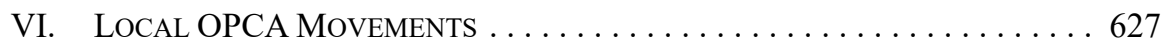

A. THE CHURCH OF THE

ECUMENICAL REDEMPTION INTERNATIONAL . . . . . . . . . . . 627

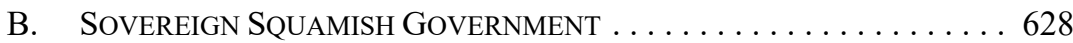

C. Tacit Supreme In Law COURT, United SOVRan Nations, AND NORTH WATCHMEN PEOPLE's EMBASSY . . . . . . . . . 628

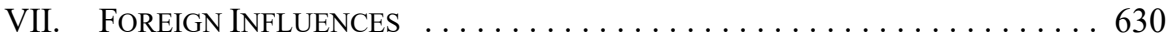

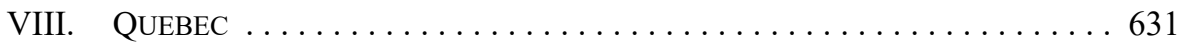

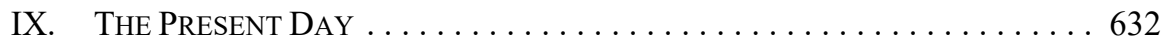

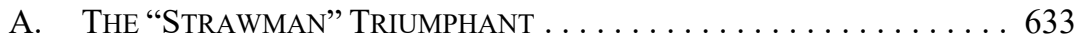

Donald J Netolitzky (PhD Microbiology, University of Alberta, 1995; LLB, University of Alberta, 2005) is a Legal Counsel for the Alberta Court of Queen's Bench. Correspondence: Donald J Netolitzky, Law Courts, 1A Sir Winston Churchill Square, Edmonton, Alberta, T5J 0R2, Email: donald.netolitzky@ gov.ab.ca. The views expressed in this article are those of the author, and not those of any other member of the Court of Queen's Bench, or the Court itself. 


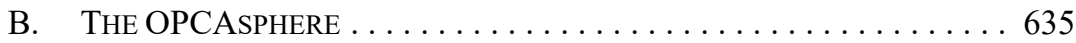

C. Court Response to OPCA Arguments . . . . . . . . . . . . . 637

X. CONCLUSION ................................ 639

\section{INTRODUCTION}

In 2012 and 2013 a series of events brought public attention to what was a hitherto unrecognized and unexpected phenomenon; there was in Canada a collection of persons who believed they were exempt from or immune to government, law enforcement, and court authority. Instead, these people, who the media generally identified as "Freemen-on-theLand," claimed they were outside Canada's laws. Freemen spokesmen appeared on television and radio, saying they and their peers were the vanguard of a new Canada where the "true" common law would be enforced, and state interference controlled. They would do what they want, and impose their so-called rights on their neighbours.

This was not a peaceful development. A man in Calgary declared that his rental property was an embassy. The house was his alone. He billed his elderly landlady, and threatened that any interference would lead to action by "Territorial Marshals."1 Meanwhile, near Grande Prairie, a group of squatters claimed they owned Crown land and would expel intruders and trappers by force. ${ }^{2}$ When RCMP officers attempted to search a rural property near Killam, Alberta for illegal firearms, they were forced to retreat after coming under fire from one occupant who wounded two officers, then killed himself. The other occupant, Sawyer Robison, fled the scene with a powerful sniper rifle and body armour. Robison, the target of the warrant, saw himself as outside government authority. ${ }^{3}$

A parallel surprise occurred in the legal community. In 2012, Associate Chief Justice Rooke of the Alberta Court of Queen's Bench released a 736 paragraph judgment, Meads v. Meads ${ }^{4}$ that collected information from 149 reported judgments where litigants had employed an array of strange legal-sounding but false concepts, which Associate Chief Justice Rooke grouped as Organized Pseudolegal Commercial Arguments (OPCAs). The broadly cited ${ }^{5}$ Meads decision explained that these ideas were sold on a commercial basis by promoters who promised immunity from taxation, criminal prosecution, government regulation, and free money. Discrete groups used OPCA concepts: the Detaxers, Sovereign

This is OPCA guru Mario Antonacci, discussed further in Part VI.C.

This event received broad media reporting, for example, "Freeman-on-the-land complaint in northern Alberta leads to arrest" CBC (9 October 2013), online: $<$ www.cbc.ca/news/canada/edmonton/freemanon-the-land-complaint-in-northern-alberta-leads-to-arrest-1.1931570>. Two persons, Paul Fiola and Shaunda Petrova, were subsequently charged. Petrova pled guilty on 4 March 2015 to illegally entering land. Fiola has absconded and faces charges relating to the squatting activities, uttering threats, possession of a firearm while prohibited, and using a firearm in the commission of an offence: "Petrova fined for occupying cabin," Grande Prairie Daily Herald-Tribune (10 March 2015), online: <www.daily heraldtribune.com/2015/03/10/petrova-fined-for-occupying-cabin>.

3 Robison was ultimately acquitted of attempted murder ( $R v$ Robison (1 May 2015), Edmonton 121307698Q1 (Alta QB)) but is facing additional weapons-related charges. Robison is a member of a poorly understood OPCA cell headed by Michael Earl. See Michael Earl, "Public Contract," online: $<$ http://michaelearl.com>.

2012 ABQB 571, 543 AR 215 [Meads].

Ibid. By the author's count, by February 2016, Meads had been cited or applied in 101 Canadian judgments (90 in relation to OPCA subjects), as well as in decisions from Australia, the Isle of Jersey, Northern Ireland, Scotland, the Republic of Ireland, and the United States. These figures only hint at the influence of this 2012 decision. Most OPCA-related litigation is not reported. 
Citizens, and the Freemen-on-the-Land. This broad category of vexatious litigation came as a revelation to many in the legal community and academia.

The unmasked OPCA phenomenon also caused a good deal of confusion. Who were these people? What did they want? Why did they express ideas that appear rife with conspiracy, and argued a strange mishmash of domestic and foreign law, legislation, and total fiction? Why did persons who used OPCA schemes not fall into any tidy pattern of political belief, social affiliation, wealth, or intent? Was the appearance of OPCA litigation part of the wellrecognized broad entry of self-represented litigants into Canadian courts?

The truth, as it often is, proved complex. OPCA ideas and litigation were not, in fact, something new, but had a history in Canada and the US that traced back for decades. For example, this was old news for government tax lawyers and civil litigators involved in debt collection. OPCA activities were not so much unknown to the courts and legal profession, but instead were clustered, by geography, time, and intent. Fringe communities were incubators for OPCA schemes that periodically expanded into a broader population. Nor was this kind of activity all that uncommon. While Meads was intended to be a comprehensive review, in fact it only captured, at best, about one third of reported Canadian judgments that related to this subject. ${ }^{6}$

OPCA ideas did not represent a legal threat to conventional authority. Canadian courts consistently rejected them. However, these schemes have a social cost: wasted court resources, unnecessary litigation expense, and sometimes devastating negative consequences to those who attempted to implement these schemes. Legal professionals and academics clearly struggled with this broader question of how to respond to the OPCA phenomenon. Context was missing, and instead replaced with guesswork and presumptions. One critical missing element is a historical foundation on which to organize this diverse category of vexatious Canadian litigation activities.

This article attempts, among other things, to construct what in biology is called a phylogeny: a family tree of related existing species and their ancestors. This tool helps explain the interrelationships of those organisms and the selective pressures that led to their appearance, divergence, and extinction. This OPCA phylogeny traces the development of groups, false but allegedly legal concepts, and key personalities. The last category is unusual. Ideas, rather than people, are usually the lynchpin of legal phenomena, but here a small number of critical persons were the direct cause of much of what is encountered today in Canadian courts. These are the OPCA gurus: the conmen who, for a price, assembled and disseminated OPCA concepts to customers who wanted to learn the secrets that would unlock special, supralegal status. To use another biological analogy, these are the Typhoid Marys $^{7}$ of the OPCA phenomenon, who spread a disease of ideas as they travelled across Canada, often at great price to their customers, and sometimes, to themselves. quarantine until her death, because she refused to stop her public food preparation activities. 
An "OPCA movement" is a group that uses common OPCA strategies and who hold or adopt a shared social perspective and typically conspiratorial alternative history. A person who employs OPCA concepts in court is an "OPCA litigant." A person who adheres to OPCA concepts but who does not necessarily use those in legal disputes or proceedings is an "OPCA affiliate." Certain sources estimate there are as many as 30,000 OPCA affiliates in Canada, however the exact source of this number is unclear. ${ }^{8}$ In the author's opinion this overestimates the phenomenon, and a more realistic figure would be an order of magnitude less. ${ }^{9}$ This population has, however, generated a considerable volume of litigation, and over 700 reported judgments. ${ }^{10}$

In Meads, Associate Chief Justice Rooke surveyed reported jurisprudence, litigation in the Alberta Court of Queen's Bench, and other materials received by that Court to develop a context for aspects of the legal, pseudolegal, social, and business characteristics of the OPCA phenomenon. However, that review was necessarily incomplete due to the source material available, and as a consequence provides a useful, but in certain senses fragmentary, landscape of the OPCA phenomenon as a whole and in specific details. Not all known gurus and OPCA movements are identified, ${ }^{11}$ and Meads significantly understates the lengthy history of the OPCA phenomenon in Canada.

This figure seems to first appear in a CBC The National news report: Adrienne Arsenault, "Finding the Freemen," The National (29 February 2012), online: <www.cbc.ca/news/canada/freemen-movementcaptures-canadian-police-attention-1.1262159>. This report credits the estimate of up to 30,000 Canadian Freemen as provided by unnamed "members of the movement and security analysts." This information has since been repeated, apparently without scrutiny, in professional sources, including a publication of the Law Society of British Columbia. See e.g. Dave Bilinsky, "The Freeman-on-the-Land movement" (2012) No 4 Bencher's Bulletin 11 at 11, online: Law Society of British Columbia $<$ www.lawsociety.bc.ca/page.cfm?cid=2627>; Southern Poverty Law Center, David Neiwert, "Canadian 'Freeman' Leader Arrested After Skipping Hearings”' (13 December 2013), online: <www.splcenter.org/ hatewatch/2013/12/13/canadian-\%E2\%80\%98freeman $\%$ E2\%80\%99-leader-arrested-after-skippinghearings $>$.

Counting the persons involved in the OPCA phenomenon is objectively difficult. However, there are a relatively limited number of forums where Freemen-on-the-Land and other OPCA affiliates discuss their concepts. These communities typically have dozens of active participants, rather than hundreds, let alone thousands. Similarly, a typical OPCA guru seminar attracts only dozens of attendees, a few hundred at most. This suggests the 30,000 figure is a substantial overestimate. Further, many OPCA belief sets, particularly those of the Freemen-on-the-Land, require that a Freeman send government actors documents such as a "Notice of Understanding and Intent and Claim of Right" to "opt out' of government and court authority and legislation. See e.g. $R v$ Sands, 2013 SKQB 115, 416 Sask R 279 at paras 6, 18-19; New Brunswick (Minister of Social Development) v C (C), 2012 NBQB 168, [2012] NBJ No 163 (QL) at para 37 [C (C)]; Re NM, 2011 CanLII 73645 (Ont Capacity and Consent Board); Viglione c Société de l'Assurance Automobile du Québec, 2012 QCCS 2742, 2012 QCCS 2742 (CanLII) at para 2. This practice provides a direct mechanism for government agencies to identify and track OPCA affiliates. The quantity of documents of that kind received by government and court actors does not support the 30,000 estimate in the Arsenault news story, but instead implies a much smaller community. The 30,000 figure also does not appear to be an accurate indication of OPCA community size at earlier points. Russell Porisky was, by far, the most successful OPCA guru of the Detaxer period. His Paradigm Education Group tax evasion group used multilevel marketing to recruit about 800 "students": $R$ v Porisky, 2012 BCSC 771, 2012 BCSC 771 (CanLII) at para 40 [Porisky Sentencing]. Paradigm Education Group was a highly structured OPCA scheme. Students were required to pay Porisky and his fellow "educators" a percentage of the their total income, typically 7 percent: Porisky Sentencing, ibid at para 38. This data provides a strong indication of the upper population limit of the Detaxer movement.

10 The author has, as of February 2016, identified 712 Canadian reported judgments that include OPCA components or relate to OPCA litigation. Of those, 149 are collected in Meads, supra note 4, 250 were decided after Meads was released, and 313 predate Meads but were not reviewed in that decision.

11 For example, Meads, ibid, does not identify the very active leading Freeman-on-the-Land guru Dean Christopher David Clifford. Clifford founded the FreemanITOBA group (formerly online at $<$ www. free manitoba.com>, now defunct), and until late 2013 actively toured and promoted his concepts. Clifford was then arrested and convicted in 2015 on drug production and firearms charges, and was sentenced on 12 January 2016: $R v$ Clifford (12 January 2016), Winnipeg CR14-01-33786 (Man QB) [Clifford Criminal Trial]. 
This article provides a more detailed historical review of the emergence of the OPCA phenomenon in Canada, the general evolution of OPCA movements and their dominant personalities, and the influence of different pseudolegal sources. This investigation relies on a wide range of resources, ${ }^{12}$ including reported and unreported jurisprudence, court files, public and social media, and materials created within the OPCA community. The author also draws from his personal experience in relation to this subject as Legal Counsel for the Alberta Court of Queen's Bench. ${ }^{13}$

It is important to stress that the survey which follows is very likely incomplete, as in many instances early OPCA activities are not well documented either in reported case law or by other sources. $^{14}$

\section{Two Separate Pseudolegal Traditions}

OPCA precursors in the United States date to the 1970s and are comparatively well documented. ${ }^{15}$ The usual historical narrative is that OPCA schemes first developed in the US and then were imported into Canada. However, a more accurate explanation is that separate sets of OPCA-type concepts emerged in each jurisdiction. These two traditions then collided in the 2000s to generate the concepts encountered in modern Canadian OPCA communities.

To date this cross-fertilization seems to have been a largely one-way process, with American ideas being introduced into a pre-existing Canadian OPCA culture. This is probably because early Canada-specific OPCA schemes rely on Canadian law and history that is not readily adapted for application in the US.

\section{The Pre-DetaXers}

"Patient Zero" for Canada appears to be a Winnipeg electronics shop owner, Gerrald Hart, who from the 1950s onward engaged in a lengthy tax avoidance campaign. The "Hart System

12 In Canada, study and documentation of the OPCA phenomenon has chiefly been the domain of what might be called amateurs or hobbyists. Some are skeptics and critics, others are OPCA advocates. In most instances, the author has not directly referenced these sources, however their efforts are what made this article possible. The author thanks these individuals, irrespective of their motivation. They have identified and saved critical information and resources that would otherwise have simply been lost, or been impossible to locate and retrieve.

13 As of February 2016, the author was directly involved in over 100 court scenarios with OPCA aspects and has reviewed many additional case files that document historical instances of OPCA activity in Canada.

14 Many of the key figures are still alive and could potentially be interviewed but were not for this study.

15 These ideas initially incubated in right wing Militia, racist Aryan Nations, and Christian Identity religious extremist communities, but became more popular during the $1980 \mathrm{~s}$ in response to the farm debt crisis of that period. Since then, the popularity of Sovereign Citizen concepts has waxed and waned. The last decade has seen a resurgence of interest and activity, and a parallel OPCA "Moorish Law" or "Moorish Nation" movement has emerged in black communities. Useful introductions to this history are provided by Wilson Huhn, "Political Alienation in America and The Legal Premises of the Patriot Movement" (1998-1999) 34:3 Gonz L Rev 417 at 419-24; Michelle Theret, "Sovereign Citizens: A Homegrown Terrorist Threat and its Negative Impact on South Carolina” (2012) 63:4 SCL Rev 853 at 860-68; Francis X Sullivan, "The 'Usurping Octopus of Jurisdictional/Authority': The Legal Theories of the Sovereign Citizen Movement” (1999) 1999:4 Wis L Rev 785 at 786-95; United States v Phillips (2 October 2014), ND Ill, Doc 1:12-CR-872 [Phillips]. 
of Effective Tax Avoidance" ${ }^{\prime 16}$ proposed many methods to frustrate tax collection, ${ }^{17}$ two of which appear in subsequent OPCA litigation. The first is documented in a reported judgment, The Queen v. Hart Electronics Limited. ${ }^{18}$ Hart would fill out a tax return with entries such as "nil," "no aspects or prospects," "never computed," "no reserves, all debt doubtful, liability unlimited," and without supporting documentation. ${ }^{19}$ The majority of the Manitoba Court of Appeal concluded that Hart's unsigned and unorthodox material was a tax return, acquitted Hart of his alleged failure to file, and refused to consider whether the return was defective or inadequate. Justice Tritschler dissented, and concluded this kind of non-response did not constitute a valid income tax return. ${ }^{20}$

The second OPCA strategy invented by Hart alleges that the Supreme Court of Canada decision Nova Scotia (AG) v. Canada (AG), ${ }^{21}$ interprets the division of direct versus indirect taxation authority under sections 91 and 92 of the Constitution Act, $1867^{22}$ such that the federal government had no jurisdiction to pass the 1917 Income War Tax Act, ${ }^{23}$ and the successor Income Tax Acts. ${ }^{24}$ The same defect allegedly exists in modern tax legislation. This scheme is still (unsuccessfully) employed by OPCA litigants. ${ }^{25}$

In the early 1990s, Alberta resident Murray Gauvreau ${ }^{26}$ collaborated with a Quebec Catholic Social Credit group, The Pilgrims of St. Michael, to mass market these early Canada-specific OPCA strategies to the Canadian public. Gauvreau openly acknowledged

16 Hart's activities are documented in George H Armstrong \& Bjarne N Aasland, Call it Extortion! (Winnipeg: AaA Publishing, 1990) vol 1 [Armstrong \& Aasland, vol 1]; George H Armstrong \& Bjarne N Aasland, Taxfighter's Sourcebook (Winnipeg: AaA Publishing, 1990) vol 2 [Armstrong \& Aasland, vol 2]. Hart himself did not produce these two texts but instead provided the authors with materials and instruction on his techniques.

17 Hart used both what might be called 'conventional' debt collection avoidance schemes and OPCA strategies. For example, Hart recommends that economically active individuals place title for property such as houses or businesses in their spouse's name, rather than their own.

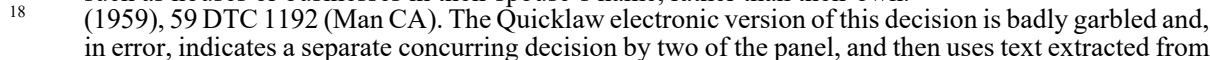
the dissent by Tritschler JA for the spurious decision. This gives the impression the Court reached the opposite result.

19 Armstrong \& Aasland, vol 2, supra note 16 reproduces several examples of Hart's corporate and personal tax returns prepared in this manner. One is dominated by a caricature of then-Prime Minister Pierre Elliot Trudeau wearing a "Benson Bonnet," titled the "Prime Clown of Canada." A sample corporate tax return is marked with Soviet hammer and sickle insignia and the statement "INCOME TAX" UNCONSTITUTIONAL MARXIST CONFISCATION!"”

20 This aspect of the Hart anti-tax scheme was subsequently rejected in $R v$ Gauvreau (16 June 1995), Grande Prairie 9404-0009S20101 (Alta QB) [Gauvreau]; R v Strang (1997), 207 AR 72 (QB) [Strang]; $R v$ Maleki, 2007 ONCJ 430, 2007 ONCJ 430 (CanLII) [Maleki]; $R$ v Josey, [1999] NSJ No 81 (QL) (Prov $\mathrm{Ct}$ ). A more mature but equally invalid variation on this scheme is to simply fill in a tax return with "n/a" entries: $R$ v Jacques, 1999 BCPC 26, [1999] BCJ No 3190 (QL), aff'd 2000 BCSC 430, [2000] 3 CTC 42, aff'd 2001 BCCA 300, 2001 BCCA 300 (CanLII); $R v$ Butterfield, 2001 BCPC 103, [2001] BCJ No 1182 (QL), retrial ordered 2001 BCSC 1420, [2001] BCJ No 2332 (QL) [Butterfield BCSC]; $R v$ Dick, 2003 BCPC 13, [2003] BCJ No 187 (QL). Yet another variation on this scheme, an income tax return with only the taxpayer's name and address, was not a valid income tax return but merely "a piece of paper which includes his address": Aasland v Canada, 2004 TCC 95, [2004] 2 CTC 2761 at para 10. Aasland is a coauthor of the two "Hart System of Effective Tax Relief" texts: Armstrong \& Aasland, vol 1, supra note 16; Armstrong \& Aasland, vol 2, ibid.

[1951] SCR 31 [Nova Scotia $(A G)$ ].

(UK), 30 \& 31 Vict, c 3, reprinted in RSC 1985, Appendix II, No 5.

SC 1917 , c 28 .

Income Tax Act, SC 1948, c 45; Income Tax Act, RSC 1952, c 148; Income Tax Act, RSC 1985, c 1 (5th

Supp) [Income Tax Act].

See e.g. $R v$ Gerlitz, 2014 ABQB 247, 589 AR 43 at para 29 [Gerlitz].

Murray Gauvreau's name is sometimes also spelled "Gavreau." 
the "Hart System of Effective Tax Avoidance" was the source of his concepts. ${ }^{27}$ In an unreported decision ${ }^{28}$ the Alberta Court of Queen's Bench rejected Gauvreau's use of both the spurious division of powers and gibberish income tax return strategies. ${ }^{29}$ Gauvreau and the Pilgrims of St. Michael seem to be Canada's first true OPCA gurus. Gauvreau's writing appeared in the "Michael Journal," ${ }^{30}$ which was periodically mass mailed to Canadian homes via Canada Post. This was accompanied by travelling speakers. ${ }^{31}$ Many key OPCA gurus identify these Michael Journal articles as the trigger for their interest in unorthodox anti-tax schemes. ${ }^{32}$

Gauvreau and Hart's constitutional division of powers argument was subsequently developed by Robert A. Marquis in an influential (in OPCA circles) self-published book: Fraud, Deception, Manipulation. ${ }^{33}$ That text, however, neglected to report that the division of powers argument had already been dismissed by Canadian courts. ${ }^{34}$

The last Pre-Detaxer influence is unusual: two pamphlets published a half century earlier that claimed fundamental flaws exist in the Canadian constitution. Both were motivated by the Social Credit movement. The first, Alberta has the Sovereign Right to Issue and Use Its Own Credit by R. Rogers Smith, ${ }^{35}$ claims that British authorities distorted the effect of the British North America Act so that Canada remained a colony. The alleged result is that the 1931 Statute of Westminster ${ }^{36}$ created Canada as a nation, but the division of powers between the provinces and federal government remained undefined. The second pamphlet, Canada

Little record remains of Gauvreau's activities. His key document was an essay, Murray Gauvreau, "Canada's Federal Income Tax is Unconstitutional," (Paper delivered at the Canadian League of Rights Seminar, Calgary, Alberta, October 1991), online: Internet Archive $<$ https://web.archive.org/web/ $20130814222521 / \mathrm{http}: / /$ www.prolognet.qc.ca/clyde/tax.htm $>$. This essay was published in a 1994 issue of the Michael Journal, and the July 1992 issue of The Canadian Intelligence Service. The latter was a right-wing anti-Semitic broadsheet published by Ron Gostick: Janine Stingel, Social Discredit: AntiSemitism, Social Credit, and the Jewish Response (Montreal: McGill-Queen's University Press, 2000) at $197-98$. Gauvreau, supra note 20.

Gauvreau's ideas became the direct basis for at least two subsequent reported decisions: Strang, supra note 20; St-Laurent v Canada, [1995] TCJ No 809 (QL) [St-Laurent]. The Michael Journal is a bi-monthly newspaper published by The Pilgrims of St. Michael that promotes Social Credit concepts in a Catholic context: Michael Journal, online: <http://michaeljournal.org/>. Gauvreau and the Michael Journal collaborated on what appears to be the earliest documented crossCanada OPCA promotion campaign: Troy Freeborn, "Pilgrims behind tax diatribe," The Terrace Standard (19 January 1994) A8.

32 See e.g. David Kevin Lindsay: "Freedom Free for All TV: David-Kevin: Lindsay Interview" (12 November 2013), online: Youtube $<$ www.youtube.com/watch? $=\mathrm{k} 18$ W8 QuhHU 8 $>$; Russell Anthony Porisky, "Intro to your Human Rights 1/20" (1 July 2007), online: Youtube <https://www.youtube.com/ watch? $=0$ oUs2MW6a9aQ>.

33 Robert A Marquis, Fraud, Deception, Manipulation: The Parliament of Canada has Deceived the Canadian People Since 1917 by Imposing Direct Taxation on Incomes and Why This Tas is Illegal (1999) [self-published]. This text is an unusually detailed analysis of the legislative and policy elements of the Canadian tax structure, and could plausibly appear to a lay person to be the product of careful research.

34 Gauvreau, supra note 20; Strang, supra note 20; St-Laurent, supra note 29; Gullison v Canada, [1993] 2 CTC 2108 (TCC), aff'd [1993] 2 CTC 33 (FCA); Hoffman $v$ Canada (1996), 112 FTR 185 (TD); Kasvand v Canada (MNR) (1995), 189 NR 222 (FCA); Mueller v Canada, [1993] 1 CTC 143 (FC (TD)); Pilon v Canada, [1996] TCJ No 792 (QL); Rosen v Canada, [1994] TCJ No 810 (QL); Sarraf $v$ Canada (MNR) (1994), 82 FTR 78 (TD).

35 R Rogers Smith, Alberta Has the Sovereign Right to Issue and Use Its Own Credit (Ottawa: 1937) [selfpublished].

36 (UK), $22 \& 23 \mathrm{Geo} \mathrm{V}, \mathrm{c} 4$. 
a Country Without a Constitution, ${ }^{37}$ was published by Social Credit member of Parliament Walter F. Kuhl. ${ }^{38}$ It reprints a 1945 speech Kuhl delivered to the House of Commons on Smith's constitutional theories and calls for efforts "to [put] our constitutional house in order." These two documents were subsequently reprinted in 1998 as The Missing Key to Canada's Future, ${ }^{39}$ an important document in the Detaxer movement period. ${ }^{40}$ Kuhl's argument formed a basis to refuse to pay income tax. The federal government allegedly had no taxation authority as that and all other government jurisdictions remained with the provinces. $^{41}$

The Pre-Detaxers appear to have had only a marginal social presence, and exposure to OPCA ideas was at this point sequestered in small, politically right-wing communities. An OPCA industry had not yet developed. That would change in the late 1990s with the emergence of Canada's first mass movement: the Detaxers.

\section{The DetaXer Movement}

The Pre-Detaxer's emphasis on income tax avoidance was maintained in the Detaxer movement, but OPCA concepts penetrated a broader population base of customers less motivated by ideology than simple greed. Detax promoters toured Canada holding information seminars and selling their techniques and materials on a commercial basis.

Important western Canadian gurus included Eldon Warman (Alberta), Ernst Friedrich Kyburz (Alberta), Sikander Abdulali Muljiani (British Columbia), David Butterfield (British Columbia), Gordon Watson (British Columbia), and Kenneth McMordie $^{42}$ (British Columbia). Initially the Alberta and British Columbia gurus advanced very different strategies, derived from either US or domestic sources.

Walter F Kuhl, Canada a Country Without a Constitution: A Factual Examination of the Constitutional Problem, online: Detax Canada $<\mathrm{http}: / /$ detaxcanada.org/kuhl.htm $>$. While undated, this pamphlet must be from at least the mid 1970s since it includes a 1976 letter from Kuhl to then Premier René Lévesque informing him that Quebec is already independent: Letter from Walter Kuhl to Premier René Lévesque (23 November 1976), online: Detax Canada<http://detaxcanda.org/kuhl.htm>.

38 Kuhl represented the Jasper-Edson riding from 1935-1949.

39 Third Option for National Unity Committee, The Missing Key to Canada's Future (Flesherton: Canadian Intelligence Publications, 1998). Canadian Intelligence Publications was a second anti-Semitic publisher operated by Ron Gostick: Stingel, supra note 27 at 198.

40 The Kuhl pamphlet is reproduced on Detaxer guru Eldon G Warman's website: Kuhl, supra note 37.

41 The Kuhl argument is explicitly rebutted in Butterfield v LeBlanc, 2007 BCSC 235, 2007 BCSC 235 (CanLII) at paras 21-25 [LeBlanc]. See also R v Dick, 2001 BCPC 245, [2001] BCJ No 2047 (QL) at para 72 [Dick 245]; $R$ v Dick, 2001 BCPC 275, [2001] BCJ No 2272 (QL) at paras 29-41 [Dick 275]; $R v$ Lindsay, 2004 MBCA 147, 187 Man R (2d) 236 at para 32; $R v$ JBC Securities Ltd, 2003 NBCA 53, 261 NBR (2d) 199 at para 4.

42 A.k.a. Byron Fox, Byrun Fox, Byron Foxx, Byrun Foxx. 


\section{A. The US Influence: WARMan, KYbURZ, MUlJiAni}

Warman, ${ }^{43}$ a former airline pilot, introduced a cluster of US-style OPCA concepts ${ }^{44}$ to Canada in the late 1990's via guru seminar activities and his website: "CDetaxCanada ${ }^{\circledR}$." In court, Warman explained that he instructed "common law" concepts that he had been taught by US guru Roger Elvick of the "Inns of Law of Wisconsin." 45 Elvick $^{46}$ is the US guru who in the 1980's initiated and promoted the "Redemption movement," a Sovereign Citizen OPCA movement that claimed money could be obtained from a secret government bank account linked to a "Strawman." Citizen belief that an individual, who is conventionally considered to be a single unit, is instead composed of two parts: a physical "man" only subject to natural law, who is linked to a legal person or "Strawman" doppelganger. This "Strawman" is a non-corporeal legal fiction that provides the mechanism by which state actors exert their otherwise illegitimate legislated authority over the physical "man.",48

This US OPCA influence is obvious in Warman's unsuccessful tax avoidance litigation. Warman claimed he was only subject to common law, ${ }^{49}$ and did not have to pay income tax because he was entirely outside government authority. Warman was a "sovereign natural

Warman is documented in Meads, supra note 4 at paras 125-29. Warman's OPCA-related activities appear to have ceased, but his website remains: Eldon Warman, DetaxCanada, online: <www.detax canada.org $>$. Much of Warman's reported litigation relates to his anti-Semitic hate-speech activities: Warman $v$ Warman, 2005 CHRT 36, 55 CHRR D/148; Warman $v$ Warman, 2005 CHRT 43, 2005 CHRT 43 (CanLII). The former decision quotes passages from Warman's website which show a strong link to US Sovereign Citizen concepts. Elvick, Warman's mentor, is also a noted anti-Semite. Newspaper reports indicate Warman fled the US in the 1980s following a dispute with the IRS that Warman alleged led to the death of his wife: Glenn Brank, "Defiant Act Turns Into Nightmare Pilot Flees US, Wife Takes Own Life After Fight With IRS," Sacramento Bee (19 February 1985) B2; Clark Brooks, "IRS Takes Offensive on Threats," Sacramento Bee (15 June 1986) B2.

Phillips, supra note 15 at 9-20; Angela P Harris, "Vultures in Eagles' Clothing: Conspiracy and Racial Fantasy in Populist Legal Thought" (2005) 10:2 Mich J Race \& L 269 at 292-97; Theret, supra note 15 at 862-68; Sullivan, supra note 15 at 795-811. Susan P Koniak, "When Law Risks Madness" (1996) 8:1 Cardozo Stud L \& Lit 65 provides a useful review of US Sovereign Citizen pseudolegal concepts. $R v$ Warman, 2001 BCCA 510, [2001] BCJ No 1761 (QL) at para 10 [Warman 510].

46 In 1991, Elvick was convicted of conspiracy to impede justice via fraudulent tax filings and was sentenced to five years incarceration (United States v Lorenzo, 995 F (2d) 1448 (9th Cir 1993)). Upon release, he resumed his OPCA activities and in 2003 pled guilty and was sentenced to four years in prison: Southern Poverty Law Center, "His 'Straw Man' Free, A Scammer Finds the Rest of him Isn't" (27 July 2005), online: Southern Poverty Law Center <www.splcenter.org/get-informed/intelligencereport/browse-all-issues/2005/summer/patriots-for-profit>.

47 The "Redemption" process is now more commonly referred to as "Accept for Value" or "A4V": Meads, supra note 4 at paras 531-43. The US variation is discussed in Theret, supra note 15 at 864-65; Phillips, supra note 15 at $15-16$.

48 This is the double/split person concept discussed in Meads, ibid at paras 417-46.

$49 \quad R v$ Warman, 2000 BCPC 22, 2000 CarswellBC 2825 at paras 4-5 [Warman 22]; Warman 510, supra note 45 at paras 9-10. By "common law" Warman means traditional and historic English common law, rather than its modern legal meaning. This 'mutant' variation of common law is discussed in Meads, ibid at paras 326-27, and more generally at Fearn v Canada Customs, 2014 ABQB 114, 586 AR 23 at paras 46-64 [Fearn]. See also James M Vaché \& Mark Edward DeForrest, “Truth or Consequences: The Jurisprudential Errors of the Militant Far-Right" (1996-1997) 32:3 Gonz L Rev 593 at 600-607. Black stresses the romanticized character of this fantastic re-imagining of the historic English common law: Robert C Black, “'Constitutionalism': The White Man's Ghost Dance”(1998) 31:2 John Marshall L Rev 513; see also Koniak, supra note 44 at 71-73 for this subject in the American context. 
citizen of the Anglo-Saxon common law. ${ }^{, 50}$ This parallels US Sovereign Citizen belief, ${ }^{51}$ and language of this kind appears in other apparently related litigation. ${ }^{52}$

Kyburz $^{53}$ published an anti-GST newsletter, "Patriots On Guard," 54 though ultimately this publication and its website became better known for its anti-Semitic content. ${ }^{55}$ Kyburz shared Warman's Sovereign Citizen-derived approach which they promoted at joint seminars. ${ }^{56}$ Kyburz's other main focus, 'flyering' campaigns, ${ }^{57}$ led to defamation proceedings. ${ }^{58}$ Muljiani, "The Untaxman," was another Warman collaborator. Muljiani was a guru for a relatively short period (1999-2002) during which he operated websites, ${ }^{60}$ held seminars, and offered a range of products, ${ }^{61}$ including a 500 page text: Becoming Free of the Canada Income Tax Act. ${ }^{62}$

\section{B. The Pre-DetaXers' SuCCESSORS: ButTerfield, WATson, MCMordie, CANAdian DetaX GrouP}

In contrast, most OPCA gurus in British Columbia used pseudolegal arguments with a Canadian origin that did not globally deny government authority, but instead looked for 'loopholes' in tax legislation.

In the late 1990s, David Edward Butterfield, "Educator and Defender of Universally Recognized Human Rights and Fundamental Freedoms,"63 operated the "Shareholders of Canada Educational Initiative." ${ }^{\prime 64}$ Butterfield's initial litigation challenged legislation that authorized the British Columbia Worker's Compensation Board and its fees, ${ }^{65}$ but

Warman 22, ibid at para 4; Warman 510, ibid at para 9.

Phillips, supra note 15 at $9-17$.

Warman's 'students' probably include the accused in $R v$ Galbraith, 2001 BCSC 675, [2001] BCJ No 2900 (QL) [Galbraith]; $R$ v Pinno, 2002 SKPC 118, [2003] 3 CTC 308 [Pinno]; $R$ v Proteau, 2002 SKPC 119, [2003] 3 CTC 118 [Proteau]. Proteau is specifically mentioned on Kyburz's website: Fred Kyburz, "Patriots on Guard" (24 September 2001), online: Internet Archive <web.archive.org/web/ 20010925035526/http://patriotsonguard.org>.

More commonly "Fred Kyburz." Kyburz died in 2009.

See "Purpose of "Patriots On Guard," Kyburz, supra note 52.

The "Patriots On Guard" website was shut down as a consequence of Warman v Kyburz, 2003 CHRT 18 (CanLII). The website's contents nevertheless remain available on the Internet Archive, ibid.

Fred Kyburz, "Planned DetaxCanada/Patriots On Guard Seminars," online: Internet Archive <web. archive.org/web/20011025000634/http://www.patriotsonguard.org/plannedsem.htm>.

"Guidelines to the 'Patriots on Guard' Flyer Program," online: Internet Archive <web.archive.org/ web/20011024224841/http://www.patriotsonguard.org/flprog.htm>.

Hall v Kyburz, 2006 ABQB 294, 2006 ABQB 294 (CanLII) at para 8, aff'd 2007 ABCA 228, 2007 ABCA 228 (CanLII). The trial decision indicates that, when stopped by police, Kyburz produced a "Copyright Notice" for his name.

Muljiani most often used the name "Alex Muljiani".

Alex Muljiani, "The UnTaxman Advisory Service" (8 November 1999), online: Internet Archive <web.archive.org/web/19991007014811/http://www.untaxman.com>; Inform Canada, online: Internet Archive <https://web.archive.org/web/20020328092128/http://www.informcanada.cc/>.

Alex Muljiani, "Ordering the full version of this book" (8 November 1999), online: Internet Archive, <web.archive.org/web/20001102104036/http://untaxman.com/orderform.pdf $>$.

The majority of this document was written by Warman, though the title page identifies Muljiani ("Rev Alex Muljiani") as the author: Eldon Warman \& Alex Muljiani, "Becoming Free of the Canadian Income Tax Act," online: Internet Archive <web.archive.org/web/19991117044555/http://www. untaxman.com/ourmission.htm>.

Herbison v Canada (Attorney General), 2013 BCSC 2020, 2014 DTC 5005 at para 52.

Online: Cyberclass < cyberclass.net/shareholders.htm>. This group was alternatively identified at times as the "Shareholders of Canada."

DADS Transport Systems Inc v Macdonald, [1996] BCJ No 1922 (QL) (SC); DADS Transport Systems Inc v Macdonald, 1996 CarswellBC 1936 (SC). 
subsequently expanded to attack income tax. ${ }^{66}$ Butterfield taught the Hart tax return and division of powers schemes, ${ }^{67}$ and Kuhl's constitutional theories. ${ }^{68}$ In 2002, Butterfield pled guilty to charges for failure to file tax returns. ${ }^{69}$

Watson ${ }^{70}$ began as an anti-abortion activist ${ }^{71}$ and refused to pay income tax because those taxes helped fund abortions. Watson used the Hart/Gauvreau division of powers concepts, ${ }^{72}$ arguments on what constituted a tax return, ${ }^{73}$ and claimed that income tax and tax reporting procedures offend the Charter. ${ }^{74}$

McMordie's anti-tax strategies evolved over time. McMordie was convicted in 2000 for failure to file income tax returns and at that point he used techniques taught by US guru David Wynn Miller. ${ }^{75}$ McMordie subsequently argued he could not defend himself because he could not obtain a current Income Tax Act due to its frequent amendment, ${ }^{76}$ and because the Income Tax Act is protected by copyright. ${ }^{77} \mathrm{He}$ was also a very early Canadian proponent of $\mathrm{A} 4 \mathrm{~V} .{ }^{78}$ McMordie then became a leading figure in the Manna Trading Ponzi scheme ${ }^{79}$ and in 2009 was fined $\$ 6$ million by the British Columbia Securities Commission. Manna Trading targeted elderly British Columbia investors who contributed to "private common-law spiritual trusts" that were allegedly exempt from the usual tax and regulatory obligations.

Butterfield BCSC, supra note 20; LeBlanc, supra note 41. Butterfield said he assisted in Galbraith, supra note 52, although David Kevin Lindsay was the guru who argued Galbraith's case in court. See Robert Koopmans, "Canadian tax laws don't apply to him, evader says," Kamloops Daily News (16 February 2000) A1; David Butterfield, "Purpose is to educate," Kamloops Daily News (26 February 2000) A6.

Sue Potvin, "Canadian Challenges Illegal Tax System" (May/June 1997) Discourse and Disclosure, online: Google Groups <https://groups.google.com/forum/\#!topic/flora.mai-not/lyvOZ9w7Vuk>.

LeBlanc, supra note 41 at paras 21-25.

Ibid at paras 3-5.

Interestingly, Watson has since publically denounced Detaxer concepts as entirely incorrect and is sharply critical of OPCA gurus, including Paradigm Education Group guru Russell Porisky and Freeman-on-the-Land Robert Arthur Menard: David Gumpert, "Lots of People Humming, 'I'm goin' to Baraboo in my mind' ... and for real ... to help Vernon Hershberger Win Food Rights; Data on Food Safety and Asthma" (28 April 2013) The Complete Patient, online: David Gumpert < davidgumpert.com/ lots-of-people-humming-im-goin-to-baraboo-in-my-mind-and-for-real-to-help-vernon-hershberger-winfood-rights-data-on-food-safety-and-asthma $>$. Nevertheless, Watson continues to challenge government regulation and authority, now as an advocate for the legal sale of unpasteurized milk products: Fraser Health Authority $v$ Jongerden, 2013 BCSC 986, 45 BCLR (5th) 328. Watson v Cull, [1992] BCJ No 2339 (QL) (SC), dismissed as abandoned 1993 CarswellBC 2594 (CA); Everywoman's Health Centre Society (1988) v Bridges (1993), 109 DLR (4th) 345 (BCSC). Constitution Act, 1867, supra note 22, ss 91-92; see Rv Watson, 2005 BCPC 59, [2005] 2 CTC 121 at paras 10-14, aff'd 2005 BCSC 1225, 2006 DTC 6393 [Watson], leave to appeal to CA refused, 2006 BCCA 233, [2006] 4 CTC 61.

73 Watson, ibid.

74 Canadian Charter of Rights and Freedoms, Part I of the Constitution Act, 1982, being Schedule B to the Canada Act 1982 (UK), 1982, c 11 [Charter]; $R v$ Watson, 2004 BCPC 208, [2005] 2 CTC 128 at paras 12-13; Watson, ibid; $R v$ Watson, 2007 BCSC 1707, [2008] 2 CTC 272.

$75 \quad R v$ McMordie, 2001 BCCA 412, 155 BCAC 21. While this judgment does not describe McMordie's strategy, it attaches a document as an appendix that is clearly written in "Millerese." See Part VII, below. $R v$ Gibbs, 2003 BCPC 527, [2004] 5 CTC 152 at paras 44-45 [Gibbs], aff'd 2006 BCSC 481, [2006] 3 CTC 223.

Gibbs, ibid at para 45.

fpOntario, "Paul McKeever, 'Michael Coren Live!' The (Un)constitutionality of Canada's Federal Income Tax" (26 September 2012), online: YouTube $<$ www.youtube.com/watch? $=$ Ctc4VyBL0aM $>$ ["Michael Coren"]. McMordie claims to use A4V to defeat criminal litigation. This "money for nothing" scheme is described in Meads, supra note 4 at paras 531-43. 
McMordie ${ }^{80}$ Filepe Marcel Naudi, ${ }^{81}$ and William Glen Kennay, ${ }^{82}$ a.k.a. "Sir Larry Leupol" formed the Canadian Detax Group, ${ }^{83}$ which promised tax immunity by becoming a "corporation sole," an incorporated office occupied by a single person.

\section{The DetaXer Scholar: DaVID KeVIN LiNDSAY}

Though prominent Detaxer guru David Kevin Lindsay became a key figure in the British Columbia OPCA community, ${ }^{84}$ he began his OPCA-related activities in the late 1990s in Manitoba. At that time, Lindsay was a founding member of "Citizens Against Government Excess," a Winnipeg-area OPCA group ${ }^{85}$ and in 1995 argued Hart/Gauvreau division of powers arguments before the Parliamentary Standing Committee on Finance. Interestingly, the chair, MP Jim Peterson, seemed familiar with these concepts. Around 2000, Lindsay organized the Edmonton-based "Individuals for Common Law" which sold a "Common Law Affidavit of Identification Card." ${ }^{86} \mathrm{He}$ currently operates the "Common Law Education And Rights" (CLEAR) Initiative, which publishes books, DVDs, and holds seminars. ${ }^{87}$

Lindsay, atypical of OPCA gurus, conducted careful legal research and developed a sophisticated, albeit self-taught, understanding of legal theory and procedure.$^{88} \mathrm{He}$ first focused on what are commonly known as the OPCA "travelling" arguments: claims that motor vehicle use does not require a license, insurance, or registration. ${ }^{89}$ In his book Rights Denied! How Your government has stolen Your Right to use the Highways You pay for, ${ }^{90}$ Lindsay credits Kyburz for introducing him to these concepts. ${ }^{91}$ This book is influenced by

McMordie also self-identified as a leader of the Ontario De-Tax group, though his operations appear to have been mainly located in British Columbia.

81 A.k.a. Bruce Stellar, see Part VII below concerning David Wynn Miller. Naudi also appears to have taught that there is no obligation to pay income tax because there is no official version of the Income Tax Act, supra note 24: see "Michael Coren," supra note 78. In 2003, Naudi was acquitted of failing to file an income tax return as the Crown had not adequately linked Naudi to his social insurance number: $R$ $v$ Naudi, 2003 BCPC 453, [2004] 2 CTC 248 [Naudi], though the reasoning for this result was subsequently rejected: $R v$ Meikle, 2008 BCPC 265, [2009] 1 CTC 184 at para 25 [Meikle]; Rv Maleki, 2007 ONCJ 186, [2007] 4 CTC 80 [Maleki 186]. In 2001, Kennay was convicted of seven counts of failing to file income tax returns: $R v$ Kennay, [2001] BCJ No 2929 (QL) (PC).

83 The Canadian Detaxing Group website between 1999 and 2001 is preserved in the Internet Archive $<$ http:www.detaxing.com>. See also Andrew Nikiforuk, "Hell no we won’t pay!" (2000) 73:9 Canadian Business 36.

84 Meads, supra note 4 at paras 100-107 provides only a partial review of Lindsay's extensive OPCA litigation activities. Lindsay himself is the subject of an additional 14 reported cases not documented in Meads.

85 House of Commons, Standing Committee on Finance, "Evidence" (28 November 1995), online: Parliament of Canada < www.parl.gc.ca/content/hoc/archives/committee/351/fine/evidence/184_95-1128/fine184 blk-e.html>.

86 "Common Law Affidavit of Indentification Card," online: Internet Archive $<$ https://web.archive.org/web /20020119174713/http://www.uncommonknowledge.net/knowledge/davelindsay.htm $>$; Dave Lindsay, "Who is Dave Lindsay?," online: Cyberclass <http://cyberclass.net/dave/davelindsay.htm>.

87 Curiously, CLEAR does not have a website.

88 See e.g. Lindsay v Manitoba, [1999] MJ No 27 (QL) (CA), leave to appeal to SCC refused [1999] SCCA No $122(\mathrm{QL})$ (where Lindsay's argument used an in forma pauperis provision that had been overlooked during legislative reform).

$89 \quad R v$ Lindsay (1999), 134 Man R (2d) 15 (CA); $R v$ Lindsay, 2002 BCSC 248, [2002] BCTC 248, aff'd 2002 BCCA 687, 180 BCAC 4; $R v$ Lindsay, 2004 BCSC 1181, 2004 CarswellBC 2081; $R v$ Lindsay, 2007 BCPC 335, [2007] BCJ No 2255 (QL). In a sense, Lindsay's litigation career has come full circle because his most recent criminal charges relate to using a bicycle without a helmet and driving without a licence: see $R v$ Lindsay, Penticton 67374571, 73474472, 79458868 (BCPC).

90 David Kevin Lindsay, Rights Denied! How Your government has stolen Your Right to use the Highways You pay for! (Winnipeg: AaA Publishing, 1999) [Lindsay, Rights Denied!].

$91 \quad$ Ibid at $66,110$. 
US “travelling" concepts and jurisprudence, but Lindsay explicitly observes that these are potentially influential but not binding authorities. ${ }^{92} \mathrm{He}$ instead develops a unique Canadian common law argument for unlimited use of roads.

Lindsay is ubiquitous in the Detaxer period. He represented many OPCA gurus and litigants, ${ }^{93}$ and, along with Watson, led a Vancouver-area Detax research group. ${ }^{94}$ This collaboration is part of a larger pattern, as Lindsay has worked closely with other OPCA promoters, including Albertan Verne Warwick, and later toured with an Ontario guru, Mozafar Maleki. ${ }^{95}$ Warwick, a professional engineer, is not the subject of any reported judgments but was involved in an Edmonton proceeding where OPCA litigants attempted to arrest a Provincial Court Judge. ${ }^{96}$ Warwick wrote an OPCA text, Clear Money, that attacks modern financial and currency practices, and charging interest.

\section{ONTARIO GURUS: KENNEDY, LAVIGNE}

During this period, the dominant Ontario anti-tax activist was a school teacher, Tom J. Kennedy (a.k.a. Tommy UsuryFree Kennedy). ${ }^{97}$ Kennedy operated the "Cyberclass" website $^{98}$ and organized annual "UsuryFree Weeks" that were an influential forum for distribution of OPCA concepts. ${ }^{99}$ Kennedy also advanced an unusual scheme to opt out of government authority by claiming copyright over one's own name. ${ }^{100}$

Ibid at $130-34$.

Lindsay has represented gurus Kennedy (Kennedy $v$ Canada (Customs and Revenue Agency), [2000] 4 CTC 186 (Ont Sup Ct J) [Kennedy]; Warman (Warman 510, supra note 45); Malecki (Maleki 186, supra note 81; Rv Maleki, 2006 ONCJ 401, [2007] 1 CTC 212 [Maleki 401]; Maleki, supra note 20) as well as many OPCA litigants (incompletely reviewed in Meads, supra note 4 at para 104).

A remarkable 'behind the scenes' window into the west coast Detaxer community is provided by an email list that discusses Detaxer concepts and litigation, "Detaxarchive," which was operated by Watson and June Yung between 2001 and 2003: Gordon Watson \& June Yung, "Forensic Taxation AdvocacyCanada (Detaxarchive)" (11 November 2001), online: Topica $<$ http://lists.topica.com/lists/Important $>$. Watson and Lindsay were the leading personalities in this community.

In 2007, Malecki was fined \$7,500 for failing to file tax returns: Maleki, supra note 20. He earlier participated in Kennedy's name copyright scheme (see Part IV.D, above). Little else is known about Maleki and his activities.

$R v$ Main, 2000 ABQB 56, 259 AR 163.

Kennedy, represented by Lindsay, unsuccessfully attempted to opt out of paying income tax as a natural person: Kennedy, supra note 93.

Cyberclass, online: <www.cyberclass.net>. This rather chaotic website archives many early Detaxer activities and litigation that are otherwise poorly documented. Kennedy also posts extensively on his blog: Tom Kennedy, The UsuryFree Eye Opener (blog), online: <usuryfree.blogspot.ca>.

Tom Kennedy, "The Tenth Annual UsuryFree Week (November 13-19, 2014)" (27 October 2014), The UsuryFree Eye Opener (blog), online: <usuryfree.blogspot.ca/2014/10/the-tenth-annual-usuryfreeweek.html >. UsuryFree Week events typically include a number of OPCA and conspiratorial speakers. Lindsay is a frequent participant.

This led to a "Good Faith Public Notice" published in the Financial Post on 23 May 2002: "Good Faith Public Notice," Financial Post (23 May 2002), online: Cyberclass <www.cyberclass.net/goodfaith 230502.jpg $>$. The author is unaware of any judicial commentary on the Kennedy version of this scheme, but strategies based on a purported copyright in a personal name have been rejected in other reported cases: Meads, supra note 4 at paras 494-504; Gravlin v Canadian Imperial Bank of Commerce, 2005 BCSC 839, 2005 BCSC 839 (CanLII) at para 9; Dempsey v Envision Credit Union, 2006 BCSC 1324, 60 BCLR (4th) 309 at paras 37-38; Hajdu v Ontario (Director, Family Responsibility Office), 2012 ONSC 1835, 2012 ONSC 1835 (CanLII) at paras 23-25; Squamish Indian Band v Capilano Mobile Park, 2011 BCSC 470, 2011 BCSC 470 (CanLII) at para 62, aff'd 2012 BCCA 126, 31 BCLR (5th) 48; Bank of Montreal v Rogozinsky, 2014 ABQB 771, 2014 ABQB 771 (CanLII) at paras 80-87 [Rogozinsky]. 
Daniel Lavigne, ${ }^{101}$ founder of the "International Humanity House," was another prominent Ontario anti-tax personality of this period. Lavigne operated the "The Tax Refusal" website, ${ }^{102}$ marketed "Tax Exemption Status Cards," 103 and claimed conscientious objection is a valid basis to reject tax obligation. ${ }^{104}$ Lavigne was subsequently convicted of child sex offences in Cambodia and is presently facing sexual interference charges in Canada. ${ }^{105}$

\section{E. Aboriginal DetaXer: Agecoutay, A.K.A. King KaneEKaneet}

Saskatchewan resident Lawrence Agecoutay, a.k.a. Sovereign King KaneeKaneet, from 2002 onward promoted a unique Detaxer variation where non-aboriginal persons were adopted into the (fictitious) Anishinabe Nations of Turtle Island, ${ }^{106}$ and purportedly obtained immunity from income tax and firearms obligations, and special investment opportunities. ${ }^{107}$ This program was expensive, requiring a $\$ 500$ application fee, then two payments of $\$ 5,000$ for ceremonies "to be given full Indian title." In 2008 Agecoutay's Indian-based OPCA concepts were rejected as a defence and he received a six-year prison sentence for operating a very large and sophisticated marijuana grow-op on the Pasqua First Nation. ${ }^{108}$

\section{F. The Natural Person: Porisky AND THE PARAdigM EdUCATION GROUP}

Early Detaxer arguments often involved some kind of technical loophole to avoid sanction, such as a taxpayer could not obtain an up-to-date, ${ }^{109}$ or certified copy, ${ }^{110}$ of the

Daniel J Lavigne is discussed in Meads, ibid at paras 130-33. That decision does not identify an additional instance where Lavigne unsuccessfully represented an OPCA litigant: $R v$ Ricci (2002), 55 WCB (2d) 406 (ONCJ), aff'd [2003] OJ No 5134 (QL) (Sup Ct J), aff'd [2005] 1 CTC 40 (Ont CA), leave to appeal to SCC refused [2004] SCCA No 551 (QL). Rv DiPalma, [2001] OJ No 3586 (QL) (Ont Sup Ct J); Zelinski v Canada (2001), 2002 DTC 1204 (TCC), aff'd 2002 FCA 330, [2003] 1 CTC 53 also appear to involve Lavigne's concepts. This website, "The Tax Refusal" $<$ www.thetaxrefusal.com>, is no longer online.

Tom Kennedy, "The 'Tax Exempt Status' Card," online: Cyberclass < www.cyberclass.net/progress. $\mathrm{htm}>$. This scheme led to warnings from the CRA \& RCMP: "Beware of phony 'tax exemption' cards" CBC News (31 May 2000), online: $<$ www.cbc.ca/news/canada/beware-of-phony-tax-exemption-cards$1.203064>$.

See Meads, supra note 4 at paras 130-33; R v Miedzwiedzki (2004), [2005] 1 CTC 103 (Ont Sup Ct J). "Daniel Lavigne-Detaxer, Humanitarian, Child Molester" (21 October 2014), online: Quatloos <www. quatloos.com/Q-Forum/viewtopic.php? $\mathrm{f}=50 \mathrm{\& t}=10282>$; "Canadian arrested on sex charges in Cambodia," National Post (14 January 2009), online: < nationalpost.com/related/topics/Canadian+ arrested+charges+Cambodia/1176563/story.html>; "Canadian jailed for indecency with Cambodian sisters: judge" Asiaone News (5 November 2009), online: <news.asiaone.com/News/AsiaOne+ News/ Crime/Story/A1Story20091105-178137.html>; Allison Loranger, "Sexual predator deported from Cambodia, arrested for child sex crimes in West Nipissing," West Nipissing Tribune (31 October 2012), online: <westnipissing.com/Sexual_predator_deported_from_Cambodia,_arrested_for_child_sex_ crimes in West Nipissing.html .

Agecoutay ("Inherent Head-Chief of the Anishinabe Nations of the Turtle Island Reserve") also personally sued Canada demanding the Crown pay him and the Anishinabe Nations annuities, and threatened the Crown with high treason. This case was eventually dismissed for inactivity: Anishinabe Nations v Canada, 2004 FC 1467, 2004 FC 1467 (CanLII). See e.g. Anishinabe.org, online: Internet Archive < https://web.archive.org/web/20030919015345/http:// anishinabe.org/>. $R v$ Agecoutay, 2008 SKQB 171, 316 Sask R 281, aff'd 2009 SKCA 100, 337 Sask R 223; see also $R$ $v$ Agecoutay, 2008 SKCA 68, 310 Sask R 224. 791, [2003] 4 CTC 157 at para 16; reviewed in Rv Gibbs, 2001 BCPC 361, [2001] BCJ No 2636 (QL) at paras $37-49$.

See e.g. $R v$ Fehr, 2002 SKPC 8, 224 Sask R 132 at para 5; $R v$ Dove (2004), [2005] 1 CTC 43 at paras 6-7 (Ont Sup Ct J). 
Income Tax Act, or that tax-related authority was improperly delegated. ${ }^{111}$ This approach sometimes even met with success. ${ }^{112}$ Other strategies attacked the taxation authority itself, for example: the Hart/Gauvreau constitutional division of power scheme, the Kuhl Statute of Westminster argument, or that involuntary taxation is contrary to the common law. ${ }^{113}$ In contrast, the US-influenced Sovereign Citizen style approach of Warman, Kyburz, and Muljiani was quite distinct with its focus on the double or split person "Strawman" concept.

The Detaxers remained a marginal social presence until Russell Porisky ${ }^{114}$ and his Paradigm Education Group advanced a "natural person" tax evasion scheme that was broadly disseminated via multilevel marketing strategies. The keystone of the "natural person" tax avoidance strategy is that, since the Income Tax Act, section 248(1) definition of "person" includes "any corporation" it must therefore exclude any natural and physical "flesh and blood" persons. The precise source of the "natural person" scheme is unclear. This scheme is first reported in Kennedy v. Canada (Customs and Revenue Agency) so it may have been his invention. However, Kennedy was represented by Lindsay, and Lindsay was involved in two cases around this period that involved other "natural person" type arguments. ${ }^{115}$ Warman directed two 2002 Saskatchewan OPCA lawsuits which used a similar, though Sovereign Citizen influenced, "natural person" scheme. ${ }^{16}$ Around the same period, the Canadian Detaxer Group was promoting that a person could become a "corporate sole," however that term first appeared in Detaxer litigation in $2005 .{ }^{117}$

In any case, while Porisky was not the first OPCA guru to argue that the Income Tax Act only applies to artificial persons and not "natural persons," 118 he certainly popularized this concept both in its basic and mature forms. The latter combined the erroneous Income Tax Act, section 248(1) argument and the Sovereign Citizen double or split person concept and its Strawman. ${ }^{119}$ The Paradigm Education Group used extensive written and video recording education materials. These were unusually professional and sophisticated, at least when compared with those of other Detax promoters. ${ }^{120}$ The Paradigm Education Group programs

See e.g. Butterfield BCSC, supra note 20.

At least one OPCA guru successfully avoided income tax-related charges by arguing that the Crown's evidence had not linked him to a social insurance number (Naudi, supra note 81), though the reasoning for this result was subsequently rejected: Meikle, supra note 81 at para 25; Maleki 186, supra note 81 . See e.g. Kennedy, supra note 93 at para 23; Rv McGrath (2001), 204 Nfld \& PEIR 334 at para 28 (Nfld $\mathrm{SC}$ (TD)).

Unlike most gurus, Porisky could point to an apparent success. In 2000, he was acquitted of four charges of failing to file a tax return: $R$ v Porisky (2000), Chilliwack 40082-1 (BCPC). Porisky told his customers this hearing was anomalous, having been relocated at the last minute to a courtroom without normal furnishings and where the judge dismissed the Crown case on her own initiative. The actual decision of Judge Maltby simply concludes the Crown had not proved its records established Porisky had not filed income tax returns.

Kennedy, supra note 93; Lindsay argued a separate "natural person" scheme, that the capitalization of names distinguishes a natural person from a legal entity: see $R v$ Linehan, 2000 ABQB 815, $276 \mathrm{AR} 383$, (an appeal of an unreported 5 July 2000 Alberta Provincial Court Decision); Dick 245, supra note 41 at paras 57-58. In the latter decision, Lindsay also argued that the right to tax was based on contract and the trial was a military proceeding.

Pinno, supra note 52; Proteau, supra note 52.

$R v$ Sydel, 2005 BCPC 413, [2005] 5 CTC 166 at para 19 [Sydel]. This is a Porisky/Paradigm Education Group case. The "Mr. Persky" in the reported judgment is Russell Porisky.

This scheme is first reported in Kennedy, supra note 93; Dick 245, supra note 41. Dick and Kennedy were both represented by Lindsay.

This variant is reviewed in detail in $R v$ Porisky, 2012 BCSC 67, [2012] 4 CTC 160, retrial ordered 2014 BCCA 146, 310 CCC (3d) 42 [Porisky].

A complete set of Paradigm Education Group materials, including the 'teaching' texts provided to Porisky's subordinate "educators," has been made available for download at the Quatloos web forum, online: Quatloos $<$ www.quatloos.com/Q-Forum/viewtopic.php?f=50\&t=10271>. 
had broad appeal outside the usual OPCA host communities. For example, its "students" included professionals and business people. ${ }^{121}$

\section{G. The DetaXers' DeCLINE}

The Detaxer movement collapsed after 2008 when critical in-court failures ${ }^{122}$ made clear that Detaxer tax evasion strategies, particularly the "natural person" argument, were legally ineffective. Criminal prosecution of "students" and "educators" from the Paradigm Education Group period continues to the present day. ${ }^{123}$ Though Kennedy continues his UsuryFree events, Lindsay is the only Detaxer guru who still actively teaches classic Detaxer motifs. ${ }^{124}$ Lindsay's years of documented in-court failure has eroded his standing in the OPCA community. This is, in a sense, ironic, as Lindsay's knowledge of court procedure, legal theory and history, and research skills are far superior to his other guru peers. ${ }^{125}$

\section{THE FREEMEN-ON-THE-LAND}

Around the year 2000, a largely distinct OPCA movement, the Freemen-on-the-Land, emerged in the extremes of politically leftist, "green," anti-globalization, marijuana advocacy, social activist, and anti-government communities. This movement was effectively

See e.g. $R v$ Klundert, 2008 ONCA 767, 93 OR (3d) 81 at para 19, leave to appeal to SCC refused, [2008] SCCA No 522 (QL) (optometrist); Sydel, supra note 117 (dentist); $R$ v Amell, 2010 SKPC 107, 361 Sask R 61, aff'd 2012 SKQB 87, 391 Sask R 196, affirmed for two offenders, retrial ordered for a third, 2013 SKCA 48, 414 Sask R 152 (naturopath); Andrew Seymour, "Ottawa dentist, wife face financial ruin for 'preposterous' income-tax dodge based on Hollywood's 'The Matrix,'” National Post (8 January 2013), online: $<$ news.nationalpost.com/news/canada/ottawa-dentist-wife-face-financial-ruinfor-preposterous-income-tax-dodge-based-on-hollywoods-the-matrix >; Teresa Smith, "Anti-tax crusaders jailed after following B.C. man's 'preposterous' evasion scheme," National Post (23 November 2012), online: < news.nationalpost.com/news/canada/anti-tax-crusaders-jailed-after-following -b-c-mans-preposterous-evasion-scheme $>$ (dentists); Canada Revenue Agency, Press Release, "Professional Engineer Fined and Sentenced to House Arrest for Tax Evasion" (30 October 2013), online: Marketwired <www.marketwired.com/press-release/professional-engineer-fined-and-sentencedto-house-arrest-for-tax-evasion-1846692.htm $>$ (engineer).

$R v$ Sydel, 2006 BCPC 346, [2006] 5 CTC 88 [Sydel 2006] was the key decision that compromised the dominant Paradigm Education Group Detaxer submovement, though Porisky argued to his followers that this decision did not have global application to his scheme: Russell Porisky, "Paradigm's Analysis of the Honourable Judge Meyers' Reasons for Judgment in the R. v. Sydel Case," Paradigm Education Group (2006), online: Mediafire <www.mediafire.com/view/4968k522c7ac1pw/analysis_of_ Sydel decision. pdf $>$.

123 Reported cases include Porisky, supra note 119; Porisky Sentencing, supra note 9; $R$ v Eddy, 2014 ABQB 164, 583 AR 217; $R$ v Eddy, 2014 ABQB 234, 583 AR 254; $R$ v Blerot, 2014 SKQB 2, 2014 DTC 5029; aff'd 2015 SKCA 69, 2015 DTC 5074; $R$ v Siggelkow, 2014 ABQB 101, 2014 ABQB 101 (CanLII); $R v$ Siggelkow, 2014 ABQB 368, 2014 ABQB 368 (CanLII); $R v$ Siggelkow, 2014 ABCA 450, 588 AR 359; $R$ v Baudais, 2014 BCSC 856, [2014] 5 CTC 183; $R$ v Baudais, 2014 BCSC 2161, 2014 BCSC 2161 (CanLII); $R$ v Fung, 2011 BCPC 326, [2011] BCJ No 2260 (QL). There are many other unreported decisions related to the Paradigm Education Group.

124 Lindsay continues to teach classic Detaxer pseudolegal schemes: see for example a 8-9 November 2014 seminar concerning the implications of the Queen's Coronation Oath, the definition of "Personhood," and the constitutional protection of property rights, online: Doublebooked Productions $<$ www.webook yourshow.com/WEBINAR-Pre-Sale.html $>$. This is despite Lindsay's consistent and ongoing in-court failures and a recent 60 -day sentence for failure to file income tax returns: $R v$ Lindsay (29 November 2012), Kelowna 70947 (BCPC).

125 A recent illustration is Lindsay's 2011 Supreme Court of Canada leave application (Lindsay $v$ Her Majesty the Queen (27 April 2011), Ottawa 34331 (SCC), online: MediaFire <www.mediafire.com/ view/dsc919r1cdqae0s/Lindsay\%202011\%20SCC\%20Leave\%20Application\%20Docket\%2034331. pdf $>$ ) [Lindsay, Leave Application]. Notably, Lindsay's application was dismissed without costs. 
the sole creation of guru Robert Arthur Menard, ${ }^{126}$ a British Columbia street comedian, who argued that all government obligations may be rejected by foisted unilateral agreements that withdraw consent. ${ }^{127}$ Menard claimed that contract is the only basis for legal authority. ${ }^{128}$ Government authority flowed from the birth certificate: a document that formed a contractual relationship between a human being and the state. The birth certificate is also a kind of commercial security that creates a "person" or "Strawman" linked to the human being. ${ }^{129}$ Menard claimed that a "person's" name is in all capital letters, while a human being is named using the dash colon name structure. ${ }^{130}$ Government bodies are corporations, and that explains why legislation has no force if a person does not consent to its effect. ${ }^{131}$

Many of Menard's ideas are clearly taken or derived from other sources, particularly Mary Elizabeth Croft, a.k.a. Mary Elizabeth Wyly. ${ }^{132}$ Croft, a resident of Canmore, Alberta, wrote a highly influential text: How I Clobbered Every Bureaucratic Cash-confiscatory Agency Known to Man ... a Spiritual Economics Book on \$\$ and Remembering Who You Are. ${ }^{133}$ Croft is an unusual figure in the OPCA community. While broadly recognized to the present day as an authority in OPCA circles, she does not seem to have taken the typical guru-forpay career path. Instead, her role is something of a "Karl Marx" to Menard's "Lenin."

Menard also appears to have borrowed extensively from Detaxer sources. For example, he adopted Lindsay's "travelling” arguments as his own. ${ }^{134}$ His Croft-derived scheme for

Menard is discussed in Meads, supra note 4 at paras 121-24. Menard has a minimal litigation footprint. He appears to largely avoid court proceedings, both personally and as an advisor, and has concealed his in-court failures, such as $R v$ Christy, Robson Square AR82367, AN37165, AP95995, AR97565, \& AT21325 (BCPC) where he unsuccessfully defended a collaborator. In $R v$ Menard (20 September 2004), Surrey 135998-1 (BCPC) Menard was arrested and pled guilty to a charge under the Transit Conduct and Safety Regulation, BC Reg 377/85, s 4(2): failure to retain and produce proof of payment for transit services. Menard claimed immunity from this specific offence in his text, Robert Arthur Menard, Violation Tickets and Appearance Notices De-Constructed, vol 2 (Vancouver: Elizabeth Anne Elaine Society, 2003).

Robert-Arthur: Menard, With Lawful Excuse (Elizabeth Anne Elaine Society and Freddie Freepickle Productions, 2011) at 37, 141-43, 167 [Menard, Lawful]. This concept and procedure parallels Sovereign Citizen techniques: see Huhn, supra note 15 at 431-33; Theret, supra note 15 at 864-66; Sullivan, supra note 15 at 801-804, 809-11; Phillips, supra note 15 at 14-15. The document that removes government authority is titled "Notice of Understanding, Intent, and Claim of Right." See e.g. $R v$ Petrie, 2012 BCSC 2110, 2012 BCSC 2110 (CanLII) at paras 41-51; Szoo'v Royal Canadian Mounted Police, 2011 BCSC 696, 2011 BCSC 696 (CanLII) at paras 17-21, 43-45 [Szoo']; ANB v Alberta (Minister of Human Services), 2013 ABQB 97, 557 AR 364 at paras 80-88 [ANB]; R v ANB, 2012 ABQB 556, 570 AR 146 at paras 46-49; Jabez Financial Services Inc $v$ Sponagle, 2008 NSSC 112,264 NSR (2d) 224 at paras $14-15,18$. This concept is generally reviewed in Meads, supra note 4 at paras 379-416.

This is the double/split person motif (ibid at paras 417-46) and a theme throughout Menard's texts: Robert Arthur Menard, Your Child Or Her Life! Deception and Evil in the Ministry of Children, Family and Community Development (Vancouver, Elizabeth Anne Elaine Society), online: Angelfire $<$ www. angelfire.com/planet/thinkfree/choldorlife.pdf $>$ at 12-13, 40 [Menard, Children]; Robert Arthur Menard, Bursting Bubbles of Government Deception (Vancouver: Elizabeth Anne Elaine Society and Freddie Freepickle Productions, 2004) at 5-9 [Menard, Bursting Bubbles]; Robert Arthur Menard, 13 Things The Government Doesn't Want You To Know (Vancouver: Elizabeth Anne Elaine Society, 2003) at 13 [Menard, 13 Things]; Menard, Lawful, supra note 127 at 16-17, 167; Robert Arthur Menard, Parking Tickets: The Scam Revealed! (Elizabeth Anne Elaine Society, 2004) at 16 [Menard, Parking]. Menard, Bursting Bubbles, ibid at 9-10. This Sovereign Citizen concept is also common in the Detaxer movement.

131 Menard, 13 Things, supra note 129 at 15-16, 19-20; Menard, Lawful, supra note 127 at 48.

132 In 2006, Croft unsuccessfully attempted to avoid paying credit card debts by arguing she, "Mary Elizabeth: Croft", is agent for her married name/"Strawman," "MARY E WYLY@®TM": Canadian Imperial Bank of Commerce v Wyly (3 May 2007), Edmonton 060301720 (ABQB). 
opting out of government interaction and jurisdiction has strong and obvious parallels to Sovereign Citizen concepts. ${ }^{135}$ Similarly, Menard's "96 is your fix" money-for-nothing scheme is little more than a redressed version of the Bill Consumer Purchase scam ${ }^{136}$ originally promoted by Warman. ${ }^{137}$ Menard's one unique contribution to OPCA pseudolaw is his argument that the secret A4V "Strawman" "birth bond" bank account is reflected in the Charter, section 7 reference to the "security of the person" (that is, "birth bond" of the "Strawman"), despite that provision's meaning having already been well defined in Canadian jurisprudence. $^{138}$

Under Menard's leadership, the Freeman movement initially experienced steady growth through astute use of Internet media, particularly Youtube videos ${ }^{139}$ and online communities. ${ }^{140}$ At present, the Freemen-on-the-Land remain the predominant Canadian OPCA movement, but one in distress and upheaval. Morale is poor; years of in-court failure have unsettled many Freemen, and post 2010, Menard's status is much reduced, particularly after his persistent failure to produce results or follow through on his many schemes, including a vigilante police force — the Canadian Common Corps of Peace Officers, ${ }^{141}$ "Freeman Valley" - an alternative community and government structure, ${ }^{142}$ a consumer note based money-for-nothing scheme, ${ }^{143}$ and "The Cirque De Soul, Eh?" - a touring arts and crafts event. ${ }^{144}$

Menard's successor, Dean Clifford, ${ }^{145}$ emerged as a popular alternative to Menard at least in part due to Clifford's emphasis on action and confrontation with government and court authorities. Clifford's status escalated dramatically following his claim to have successfully used Freeman techniques to obtain release after his arrest on 3 February 2013 for a variety

See Phillips, supra note 15 at 10-17; Harris, supra note 44 at 292-97; Theret, supra note 15 at 862-68; Sullivan, supra note 15 at 791-811; Huhn, supra note 15 at 430-33.

Meads, supra note 4 at paras 544-47.

See the commentary on promissory notes on the DetaxCanada website, online: DetaxCanada $<$ www.detaxcanada.org $>$, and a file that expands on the methodology, online: DetaxCanada $<$ www. detaxcanada.org/promissory\%20note.rtf>.

The author is not aware of a reported judgment where an OPCA litigant advanced Menard's unorthodox interpretation of the Charter, supra note 74, s 7.

Menard was one of the first OPCA gurus to effectively use this form of social media as a recruitment tool. Many of his videos may be viewed on his "mrmitee" Youtube channel, online: Youtube $<$ www.youtube.com/user/mrmitee $>$, though some have been deleted.

The most prominent is the World Freeman Society website, formerly at <www.worldfreeman society.org>, now online: World Freeman Society < worldfreemansociety.ca>. Menard identifies himself as the Director of this organization,"Interview with World Freeman Society Director Robert Menard," Global News (11 September 2013), online: <globalnews.ca/video/832893/interview-with-worldfreeman-society-director-rob-menard $>$.

More commonly referred to as "C3POs" (website formerly hosted at <www.c3po.ca>).

Outlined in the booklet Robs [sic] Very Cunning Plan (Freeman Society - Canada, 2009), online: $<$ www.anarchiel.com/downloads/rvep.pdf $>$.

Association of Canadian Consumer Purchasers, online: Internet Archive < web.archive.org/web/201305 28032051/http://consumerpurchasers.ca $>$. See also mrmitee, "Canada Law Lesson: Consumer Purchases and You - Paying By Consumer Note" (13 March 2012), online: Youtube $<$ https://www.youtube.com/ watch?v=TyQSEcdY6Mc $>$; Robert Menard, "Consumer purchase theory," Global FACT Radio (25 March 2013), online: <www.blogtalkradio.com/globalfactradio/2013/03/25/global-fact-radio-robertmenard-consumer-purchase-theory>; Association of Canadian Consumer Purchasers, online: Facebook $<$ www.facebook.com/groups/457133764361174>.

The Cirque De Soul, eh?, online: Facebook <www.facebook.com/groups/121245771402749>.

See generally supra note 11 . Clifford has a white supremacist, skinhead background, "Canadian Freeman Movement: Ties to Extremism" (4 January 2013), Anti-Racist Canada (blog), online: <antiracistcanada.blogspot.ca/2013/01/canadian-freeman-movement-ties-to.html>; "Dean Clifford and Bill Noble: Emails" (24 November 2014), Anti-Racist Canada (blog), online: <anti-racistcanada.blogspot.ca/ 2014/11/dean-clifford-and-bill-noble-emails.html $>$. His early customers were largely drawn from that group. Clifford now presents himself as a "blue collar" anti-government resister. 
of minor offences. Clifford spent close to a month in remand but his charges were then stayed.

Clifford was largely discredited following his arrest on 24 November 2013, his extended pretrial detention, and his 2015 conviction on firearms and narcotics production charges. ${ }^{146}$ Clifford received a three-year sentence. While in detention, Clifford unsuccessfully sued judges and government actors in retaliation for that arrest and detention, which Clifford claims was unauthorized. ${ }^{147} \mathrm{He}$ has also filed numerous applications for release on a variety of pseudolegal bases. ${ }^{148}$ Clifford's post-detention activities have also led to additional Manitoba Provincial Court proceedings for threats to kill or cause bodily harm to law enforcement personnel. ${ }^{149}$

Many Freeman affiliates have now moved to other gurus or movements.

\section{LOCAL OPCA MOVEMENTS}

Both the Detaxers and Freeman movements had a broad geographic influence in Canada, with participants in many jurisdictions. This has been supplemented by OPCA gurus with restricted local activity, ${ }^{150}$ and a number of smaller local movements with members largely drawn from a more limited geographic region.

\section{A. The CHURCH OF THE ECUMENICAL REDEMPTION INTERNATIONAL}

The best documented of these local movements is the Church of the Ecumenical Redemption International (CERI), a now largely inactive OPCA movement centered on the Edmonton area. CERI dates back at least to the early 2000s and appears to have begun as a splinter of the Church of the Universe, a "pot church."151 CERI and its members have an extensive, though largely unreported, litigation history, much of which is documented on the “All Creator's Gifts" website. ${ }^{152}$ CERI and its guru “minister" Edward Jay Robin Belanger ${ }^{153}$

146 Clifford Criminal Trial, supra note 11

147 Clifford v Manitoba, 2014 MBQB 192, 309 Man R (2d) 309 [Clifford]; Clifford v The Queen (16 May 2014), Winnipeg T-869-14 (FC) [Clifford FC].

$148 \quad R v$ Clifford, Winnipeg, CR13-01-32571 (Man QB): applications on 6 March 2014, 17 April 2014, 1 May 2014, 21 July 2014; Clifford Criminal Trial, supra note 11: applications on 30 September 2014, 9 October 2014, 12 June 2015; Clifford v The Queen (15 September 2014), CI14-02-03064 (Man QB) (application).

149 Ian Hitchen, "Freemen rep clashes with judge, tossed from court," Brandon Sun (3 October 2014); Ian Hitchen, "Accused threatened police: Crown," Brandon Sun (9 December 2014).

150 The most prominent of these was John Ruis Dempsey, a British Columbia OPCA guru who (falsely) claimed to be a Filipino lawyer. Dempsey's activities are documented in detail in Meads, supra note 4 at paras 109-20. Dempsey's litigation, which was less a movement than a one-man crusade, apparently ended after he was sentenced to 30 days incarceration for his failure to cease unlicensed practice as a lawyer. An archived copy of Dempsey's website remains available: "The People v The Banks — The Greatest Battle," online: $<$ blog.lege.net/financialoutrage.org.uk/freewebs.com/classaction/index.htm $>$.

$151 \quad R v$ Baldasaro, 2009 ONCA 676, 265 OAC 75; $R$ v Baldasaro, [2006] OTC 134 (Sup Ct J), aff'd (2006), 213 CCC (3d) 89 (Ont CA), leave to appeal to SCC refused, [2006] SCCA No 474; Tucker v Canada, 2003 FC 1008, 239 FTR 81. In 2001, Belanger self-identified as a druid and minister of the Church of the Universe: Reverend Damuzi, "Minister raises hell in court" Cannabis Culture (26 December 2001), online: <www.cannabisculture.com/content/2001/12/26/2213>.

152 See online: All Creator's Gifts $<$ www.allcreatorsgifts.org $>$. The notable exception are cases that involve Kazimierz Crischuk (a.k.a. "Mythlim-Axkw"), who advanced CERI arguments as well as claiming special status due to alleged aboriginal affiliation: $R v$ Crischuk, 2007 BCPC 470, [2007] BCJ No 2969 (QL) [Crischuk]; $R v$ Crischuk, 2010 BCSC 716, 2010 BCSC 716 (CanLII) [Crischuk 716]; $R v$ 
claim the King James Bible trumps Canadian law because the Coronation Oath represents a contract between Queen Elizabeth and her subjects to uphold Biblical law. ${ }^{154}$ Belanger also appears to be the original source for an OPCA argument that section 32 of the Charter means all Canadian legislation applies only to government actors and institutions. ${ }^{155}$ This argument has recently become popular in Freeman-on-the-Land circles. ${ }^{156}$

\section{B. SOVEREIGN SQUAMISH GOVERNMENT}

The Sovereign Squamish Government (SSG), headed by Irene Gravenhorst, is another local Canadian OPCA movement. The SSG claimed not only to be an independent government outside of Canadian law, but also declared superior jurisdiction over legitimate Squamish Indian Bands. ${ }^{157}$ The SSG appears to have become inactive after one member, Warren Fischer, attempted to use SSG techniques to evade his income tax obligations. He was convicted, ${ }^{158}$ sentenced to six months incarceration, and prohibited from working as a Chinese medicine practitioner and acupuncturist. ${ }^{159}$

\section{Tacit Supreme In Law Court, United Sovran Nations, AND North Watchmen PEOPLE's EMbassy}

At present, the most significant local OPCA movement is the Tacit Supreme In Law Court and the United Sovran Nations (TSILC/USN). The TSILC/USN first appeared in Montreal in the late 2000s, but abruptly disappeared in $2009,{ }^{160}$ only to resurface in Calgary in $2012 .{ }^{161}$ The TSILC/USN first attracted significant attention in 2013 when its leader, "Senior Chief

Crischuk, 2010 BCSC 1165, [2011] 1 CTC 149 [Crischuk 1165], appeal classified as frivolous, $R v$ Crischuk, 2010 BCCA 391, 2010 DTC 5141. Crischuk is an accountant who received pay to file fraudulent OPCA-based income tax returns: Crischuk 716, ibid; Crischuk 1165, ibid.

CERI and Belanger are discussed in Meads, supra note 4 at paras 134-39, 183-88.

This argument is rejected in Crischuk, supra note 152 at paras 11-12.

Charter, supra note 74, s 32; Reverend Damuzi, "Religious defence drives authorities mad," Cannabis Culture (1 June 2001), online: <www.cannabisculture.com/content/2001/06/01/1948>.

$R v$ Petrie, 2012 BCSC 2109, 2012 BCSC 2109 (CanLII) at paras 68-84 [Petrie]; Gerlitz, supra note 25 at paras 34-37; $R$ v Zombori, 2013 BCSC 2461, 2013 BCSC 2461 (CanLII) at para 28.

The SSG operates several websites: Sovereign Communications Network, online: $<$ sovcom.net $>$ and Sovereign CSkwxwú7mesh-Squamish ${ }^{\mathrm{TM}}$ Government $\left(\mathrm{CSSG}^{\mathrm{TM}}\right)$, online: $<$ www.sovsquamishgov.org $>$. The SSG has, on at least one occasion, unsuccessfully attempted to exert its authority over its subordinate bands: Zig Zag, "Crazy and Confused, Con Job, or Cult?" (1 May 2011) Warrior Publications, online: <warriorpublications.wordpress.com/2011/05/01/crazy-and-confused-con-job-orcult/>; educatedindian (23 November 2012 at 4:28 pm), Comment on NAFPS Forum, online: $<$ www.newagefraud.org/ smf/index.php?topic $=3887 . \mathrm{msg} 32596 \# \mathrm{msg} 32596>$.

$R v$ Fischer, 2013 BCPC 154, 2013 DTC 5125.

College of Traditional Chinese Medicine Practitioners and Acupuncturists of British Columbia $v$ Fischer, 2014 BCSC 985, 2014 BCSC 985 (CanLII) [Fischer].

Little documentation remains from this period. A very incomplete copy of the Sovran Nations Embassies of Mother Earth website is archived, online: Internet Archive <web.archive.org/web/20130719211 644/http://sovrannationsembassies.com $>$. A series of videos that feature Antonacci also remain available, online: Youtube <www.youtube.com/user/SohhieTits4/videos>. While in Montreal, Antonacci collaborated with Maryjane Blackshear, a prosperity program promoter (Blackshear v Canada, $2013 \mathrm{FC}$ 590, 2013 FC 590 (CanLII); "SUNKE Temple Trust," online: <www.sunketempletrust.com>; Re AS, 2014 ABPC 300, 2014 ABPC 300 (CanLII).

A large series of websites, now offline, were put up in this period, including "The Tacit Supreme In Law Court," online: <www.tacitsupremeinlawcourt.org/>, "The United Sovran Nations," online: <united sovrannations.org $>$. Antonacci also operated a business, the "CPC Universal Group," that purported to be a building contractor but also offered banking and financial services (online: $<$ www.CPCGroup.ca $>$ ). This business is now the target of legal proceedings in Alberta for illegal renovation activities: Alberta Government, Announcement, “Alberta protects homeowners through sting operation" (2 December 2013), online: Alberta Government <alberta.ca/release.cfm?xID=354800AE675C6-C063-CC3F-9D9237 E87604D113>. 
Justice Andreas Pirelli" became involved in a highly publicized confrontation with his Calgary landlord. Pirelli had declared his rental residence an embassy. ${ }^{162}$ It subsequently emerged that Pirelli was actually Mario Antonacci, who in 2009 absconded from Quebec part way through his trial on assault charges. Antonacci was arrested, returned to Quebec, pled guilty, and was sentenced to two years and nine months in gaol. ${ }^{163}$

At this point the TSILC/USN and its Edmonton area affiliate, the North Watchmen People's Embassy ${ }^{164}$ (NWPE), ceased public activity. However, these groups have recently re-emerged in correspondence directed to Alberta courts. The TSILC/USN and NWPE were involved in 2013 Crown land squatting activities in the Grande Prairie area ${ }^{165}$ and have recently attempted to interfere in the court proceedings against one of those squatters, Paul Fiola.

Unlike most OPCA movements, the TSILC/USN maintains a low public profile. It has its own vigilante police force, the "Territorial Marshals," and claims to operate "Tacit Supreme in Law" courts with jurisdiction that is separate and superior to those of the Canadian Government.

The belief system and pseudolegal concepts of the TSILC/USN are poorly documented, but appear to have a basis in purported aboriginal rights and are probably most closely related to ideas used by US Sovereign Citizen fake Indian bands. ${ }^{166}$ During the embassy confrontation, Antonacci and the TSILC/USN were commonly identified in the media as Freemen-on-the-Land. The author believes that this association is incorrect. ${ }^{167} \mathrm{He}$ has never encountered any use of that language in TSILC/USN materials, nor is the author aware of any occasion where a TSILC/USN affiliate has identified themselves in that manner.

This event was broadly reported, see for example Canadian Press stories on this subject archived by the Huffington Post, online: < www.huffingtonpost.ca/news/andreas-pirelli/>.

163 Christiane Desjardins, "La prison pour le fugitif Antonacci" La Presse (28 June 2014), online <www. lapresse.ca/actualites/justice-et-affaires-criminelles/process/201406/28/01-4779575-la-prison-pour-lefugitif-antonacci.php>.

164 "North Watchmen People's Embassy," online: Internet Archive <web.archive.org/web/2014051717 4330/http://nw-pe.org/s.

165 Supra note 2.

166 For example, the Little Shell Pembina Band ("Extremism in America: Little Shell Pembina Band," online: Anti-Defamation League $<$ archive.adl.org/learn/ext us/little_shell.html?LEARN_Cat=Extrem ism\&LEARN SubCat=Extremism in America\&xpicked $=\overline{3} \&$ item $=$ little shell $>$ ) and the Tuscarora Nation ("Sovran Tuscarora Nation,"' online: <tuscaroranationnewyork.com`; "Sovereign Trust," online: $<$ web.archive.org/web/20140111044419/http://sovereigntrust.info/>).

167 Menard and other Freeman spokespersons also publically rejected this alleged affiliation. Sherri Zickefoose, "Freeman guru says Calgary renter's actions are not condoned by movement" Calgary Herald (27 September 2013), online: <http://www.calgaryherald.com/news/freeman+guru+says+ calgary+renter+actions+condoned+movement/8972869/story.html $>$. 


\section{FOREIGN INFLUENCES}

While the earliest Canadian OPCA activities were a domestic product, US gurus and concepts also have a long history in Canada.

David Wynn Miller appears to be the first US guru active in Canada, ${ }^{168}$ coordinating his activities with an early Canadian OPCA guru, Filepe Marcel Naudi, a.k.a. "Bruce Stellar."169 Miller's techniques are comparatively uncommon in Canada and are notoriously complex and peculiar, even for this domain. "Millerese" materials use a highly stereotypic and peculiar language structure, "Quantum-Language-Parse-Syntax-Grammar." ${ }^{\text {"170 }}$ Miller himself is a bizarre figure. He introduces himself as "David Wynn Full Colon Miller." A former machinist and welder, Miller claims to have become the king of Hawaii after he turned Hawaii into a verb. Miller says he is fluent in numerous languages, has an IQ of 200, and that he has not aged since he died and was resurrected at age $25 .{ }^{171}$ Miller appears to be the source of the ubiquitous dash colon naming motif. ${ }^{172} \mathrm{He}$ says this variation on a name transforms a human into a "prepositional phrase," which is purportedly outside state authority.

Winston Shrout is likely the most influential foreign guru. Shrout toured Canada in the early 2000s, and taught the A4V money-for-nothing technique and the classic Sovereign Citizen motif that government authority is restricted to admiralty law and commerce. ${ }^{173}$ Shrout's schemes do not appear to include a variation localized for Canada.

This cross-border information flow process continues at present. Glenn Winningham Fearn, ${ }^{174}$ a dual US and Canadian citizen and brother of Pre-Detaxer Murray Gauvreau, has taught Sovereign Citizen concepts in Canada. ${ }^{175}$ In 2014, Fearn was found guilty and sentenced to four months incarceration for smuggling weapons into Canada. ${ }^{176}$ Upon release, he absconded into the US in breach of his probation conditions. Between arrest and trial,

. Council v Falamaki, [2009] FMCA 1204; Wollongong City Council v Falamaki, [2010] NSWLEC 66. The latter decision contains excerpts from Miller's in-court testimony.

See "Truth Radio," online: Internet Archive < web.archive.org/web/20010608224447/http://www.bruce stellar.com/radio. html>; "Study," online: Internet Archive <web.archive.org/web/20011203120451/ http://www.brucestellar.com/study.html >.

See "Judge: David-Wynn: Miller," online: <dwmlc.com/>

Mark Potok, "Full Colon Miller" Intelligence Report (15 April 2003), online: Southern Poverty Law Center $<$ www.splcenter.org/get-informed/intelligence-report/browse-all-issues/2003/spring/full-colonmiller>.

Meads, supra note 4 at paras 203-208.

Shrout's primary website is "Winston Shrout: Solutions in Commerce," online: <wssic.com/>. However, a large number of his videos are archived on Youtube, including his own Youtube channel: "Winston Shrout," online: Youtube <www.youtube.com/user/WinstonShrout $>$. Shrout's seminars in Calgary, Kelowna, Toronto, and Vancouver were recorded and are sold on Shrout's website in \$195 DVD packages: "International Seminars," online: Winston Shrout: Solutions in Commerce < www.wssic.info/ lecture-library/seminars/international-seminars/>.

Fearn, who usually self-identifies as "Glenn Winningham of the House of Fearn," operates the

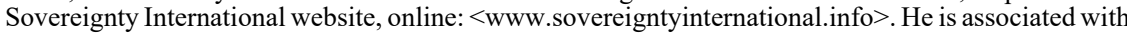
the fictitious "republic of Texas" government, at one point acting as its Speaker of the House of Representatives, "Private Information Share," online: <www.tapesite.com/index22>.

See Meads, supra note 4 at paras 176-81; Fearn, supra note 49 at paras 46-64.

$R v$ Fearn, 2014 ABPC 56, 586 AR 148; $R v$ Fearn, 2014 ABPC 58, 586 AR 173. 
Fearn toured Western Canada promoting his ideas. ${ }^{177}$ Fearn $^{178}$ reviews but understates Fearn's history as an OPCA affiliate and guru, which extends back to at least $1999 .{ }^{179}$

The latest wave of gurus originate from other Commonwealth countries, including Michael Tellinger (South Africa), Karl Lentz (United Kingdom), Jon Witterick and Mark "Ceylon" Laining (UK). Tellinger is a relatively new arrival. He has recently toured Canada promoting his "Ubuntu Contributionism" concept and political party ${ }^{180}$ and teaches how to allegedly pay debts with promissory notes. ${ }^{181}$ Tellinger has a colourful background. He was a 1980's pop star who subsequently wrote a series of books that claims humanity is a degenerate slave species created by extraterrestrials to mine gold. ${ }^{182}$

Lentz, originally a US Sovereign Citizen, has become a significant figure in the UK Freeman-on-the-Land community. He claims to have located the Court of Queen's Bench: a secret, long believed abolished, common law court where Freeman remedies may be obtained. Lentz has recently conducted at least one speaking tour of Western Canada. ${ }^{183}$

Witterick and Laining operate the "Get Out OfDebt Free" website ${ }^{184}$ that promotes foisted unilateral agreements, promissory notes, and $\mathrm{A} 4 \mathrm{~V}$ techniques for debt elimination. This UK website has a variant directed specifically to Canadian customers. ${ }^{185}$

\section{QUEBEC}

The OPCA phenomenon emerged late in Quebec, with most reported judgments dating after 2010. These disclose two schemes:

1. an essentially unmodified American-style A4V money for nothing mechanism to discharge debts, ${ }^{186}$ and

See e.g. Eventbrite, "Sovereignty International," online: <www.eventbrite.ca/o/sovereignty-inter national- 1843585047 ? $\mathrm{s}=3096457>$. Videos of these seminars are available on Fearn's Youtube channel: "Sovereignliving," online: Youtube <www.youtube.com/channel/UCIsP6Md6RIP0gyurlAUFlJA>. See supra note 49 at paras $103-104$

179 Fearn appears in newspaper reports about legal proceedings against early Detaxers Denise and Richard Rosenberg: Bud Robertson \& Aldo Santin, "Taxman fights back at family," Winnipeg Free Press (11 September 1999). Fearn also represented Denise Rosenberg in Federal Court: ITA v Rosenberg, Winnipeg ITA-8790-97 (FC).

See e.g. "Ubuntu Liberation Movement," online: <www.ubuntuparty.org.za $>$; "Ubuntu Party Canada," online: <www.ubuntupartycanada.org $>$. The Ubuntu Party received 0.04 percent of the popular vote in the 2014 South African general election: "Results Reports South Africa: Party Support," online: $<$ www.elections.org.za/content/NPEPublicReports/291/Party\%20Support/National_613.pdf $>$.

Michael Tellinger, "How to Create your own promissory Notes" (18 December 2014), online: Youtube $<$ www.youtube.com/watch?v=dbu5ULgIA $>$.

See Michael Tellinger, Slave Species of The Gods: The Secret History of the Anunnaki and Their Mission on Earth, 2nd ed (Rochester, Vt: Bear \& Company, 2012); Michael Tellinger, African Temples of the Anunnaki: The Lost Technologies of the Gold Mines of Enki (Rochester, Vt: Bear \& Company, 2013); "Slave Species," online: <slavespecies.com>.

183 "Karl Lentz weekend on Common law," online: <www.kingmotorsupply.com>.

184 "Get Out Of Debt Free," online: <www.getoutofdebtfree.org >

185 See Rogozinsky, supra note 100 at paras 55-73.

Bank of Nova Scotia c Fortin, 2012 QCCQ 994, 2012 CarswellQue 1199 (WL Can), reconsideration rejected 2012 QCCQ 3932, 2012 CarswellQue 5302 (WL Can); Banque Canadienne Impériale de Commerce c St-Pierre, 2013 QCCQ 1584, 2013 CarswellQue 2227 (WL Can); Banque de Nouvelle-Écosse c St-Pierre, 2013 QCCQ 1583, 2013 CarswellQue 2228 (WL Can); Banque Manuvie du Canada c Hamel, 2012 QCCS 2187; Banque Nationale du Canada c Stefanelli, 2013 QCCS 2974, 2013 CarswellQue 6836 (WL Can); Caisse Désjardins des Métaux Blancs c Langlois, 2012 QCCS 1443, 2012 CarswellQue 3391 (WL Can); Caisse Desjardins Vallée de la Matapédia c Guénette, 2012 QCCQ 
2. an argument that debts cannot be collected as the loan contracts do not conform with the Bills of Exchange Act, ${ }^{187}$ section 188-192 requirements for a "consumer note." $" 188$

The latter scheme is different from the "bill consumer purchase" money for nothing scheme discussed in Meads ${ }^{189}$ and which Menard currently promotes via his Association of Canadian Consumer Purchasers. The Quebec variant instead seems to match an apparently unconnected Alberta OPCA litigation from a decade before. ${ }^{190}$

There is surprisingly little indication of Freeman-on-the-Land ${ }^{191}$ or other Commonwealth influences in Quebec. ${ }^{192}$ Instead, most Quebec OPCA schemes appear to draw directly from the US Sovereign Citizen movement. ${ }^{193}$

\section{The Present DAY}

Throughout the 2000s, Canadian and American OPCA concepts became increasingly cross-contaminated. Foreign concepts and legislation, such as $\mathrm{A}_{4} \mathrm{~V}^{194}$ and the Uniform Commercial Code, ${ }^{195}$ became common features in Canadian OPCA legal proceedings, sometimes alone and sometimes in combination with domestic concepts. ${ }^{196}$ This borrowing

1095; Compagnie de fiducie du Groupe Investors ltée c Ouellet, 2011 QCCS 7508; Canadian Imperial Bank of Commerce c Fortin, 2012 QCCQ 968, 2012 CarswellQue 1198 (WL Can); Droit de la famille - 123381, 2012 QCCS 6120; BanqueLaurentienne du Canada c Carabes, 2011 QCCS 5832, 2011 CarswellQue 12104 (WL Can), aff'd 2012 QCCA 214, 2012 CarswellQue 906 (WL Can); Banque Laurentienne du Canada c Renaud, 2012 QCCS 4025, 2012 CarswellQue 8547 (WL Can); Services de Financement TD Inc c Michaud, 2011 QCCQ 14868, 2011 CarswellQue 13245 (WL Can); Xceed Mortgage Corp c Pépin-Bourgouin, 2011 QCCS 2116, 2011 CarswellQue 4519 (WL Can). Bossé v Farm Credit Canada, 2014 NBCA 34, 419 NBR (2d) 1, leave to appeal to SCC refused, 2014 CanLII 74399 [Bossé], likely belongs to this group.

187 RSC 1985, c B-4.

188 Banque Royale du Canada c Minicozzi, 2013 QCCQ 6566, 2013 CarswellQue 6850 (WL Can), aff'd 2013 QCCA 1722, 2013 CarswellQue 9963 (WL Can); Banque Royale du Canada c Dobe, 2012 QCCS 4490, 2012 CarswellQue 9626 (WL Can); Banque Toronto-Dominion c Demers, 2012 QCCS 2911, 2012 CarswellQue 6615 (WL Can); Viglione c Banque de Montréal, 2013 QCCS 2961, 2013 CarswellQue 6305 (WL Can) [Viglione].

189 Supra note 4 at paras 544-47.

$190 \quad$ Whitfield v Chrysler Credit Canada Ltd, 2001 ABQB 497, 294 AR 376; Gladue v Asset Recovery Management \& Sales, [1997] AJ No 1251 (QL) (QB).

191 Freeman-type strategies appear in Goyette c Agence du revenu du Québec, 2013 QCCQ 16299, JE 2014190; Notaires (Ordre professionnel des) c Lalonde, 2014 CanLII 47759 (Chambre des Notaires du Québec); Viglione, supra note 188.

192 UK Freeman-on-the-Land guru Veronica Chapman is the source for the documents and strategies used in Gratton c Service de Police de la Ville de Gatineau, 2012 QCCS 6190, 2012 CarswellQue 13254(WL Can) [Gratton]. The Plaintiff in CMc Québec (Emploi et Solidarité sociale), 2014 QCTAQ 10498, 2014 CanLII 62958 (Tribunal Administratif du Québec) used material with Australian UCADIA motifs (see n 244, below).

193 Quebec also hosts several idiosyncratic OPCA litigants. One is Jacques-Antoine Normandin, the subject of at least 25 reported cases, and Alain Painchaud, who declared himself king of his own sovereign republic: Painchaud c Capital Transit inc, 2014 QCCS 4071, 2014 CarswellQue 8479 (WL Can); Painchaud c Capital Transit inc, 2014 QCCS 4072, [2014] JQ no 8854 (QL); Capital Transit inc c Painchaud, 2014 QCCS 5624, [2014] JQ No 13307 (QL); Capital Transit inc c Painchaud, 2014 QCCS 5780, [2014] JQ No 13581 (QL).

194 Reviewed in Meads, supra note 4 at paras 531-43.

$195 \quad$ See ibid at paras $150,228,331$.

196 See ibid at para 331. Dennis Larry Meads, the OPCA litigant in that decision, clearly based his litigation strategy on an unidentified US OPCA source: at paras 148-53. The OPCA litigant in Mercedes-Benz Financial v Kovacevic, [2009] OJ No 783 (QL) (Ont Sup Ct J), appears to have advanced an essentially "pure US" type scheme. Sometimes, such as in Szoo', supra note 127, both US and Canadian influences are obvious. That litigant used documents with the same language as those employed by Meads, but also employed Freeman-on-the-Land documents propagated by Menard, including a "Notice of 
is obvious in both Freeman and later Detaxer litigations. For example, the double or split person concept and its "Strawman" have no antecedent in Canadian law and clearly represent motifs derived from the US Redemption movement by gurus such as Warman, Porisky, and Menard. Menard has also promoted US concepts such as A4V. ${ }^{197}$ The result is something of a conceptual amalgam, with gurus and affiliates paying little attention to the legal environments that are the sources of their ideas. ${ }^{198}$ This influx of American OPCA concepts has also led to a fundamental shift in the Canadian OPCA community and its character.

\section{A. THE "STRAWMAN" TRIUMPHANT}

A fascinating aspect of the merger of US and Canadian OPCA traditions is that one particular motif has become all but universal — the split or double person "Strawman." Every single OPCA guru identified in this article who is presently active advances some form of the "Strawman" motif in their materials. ${ }^{199}$ That even includes the usually pragmatic and well-informed Lindsay, who nevertheless attempts to rationalize the "Strawman" but via Commonwealth sources. ${ }^{200}$

This misconception that a "legal person" is somehow distinct from a physical human being, and is then linked to the physical person as a kind of parasitic twin is ubiquitous in modern OPCA theory. The existence of the "Strawman" is explained with a specific historical and pseudolegal narrative that casts government actors in a very negative light.

For example, the Sovereign Citizen movement has broadly re-imagined certain critical historical events and their effect on the status and rights of US residents. ${ }^{201}$ Freeman-on-theLand guru Robert Menard created an analogous shadow version of Canadian history where bankers and corporations that masquerade as governments entrap Canadians via a secret contract, which takes the form of a financial document: the birth certificate "Birth Bond."

Both these false histories share the split or double person concept: a belief that a physical person and legal person are separate. This idea is often expressed by OPCA gurus as "I am not a person, but I have a person." 202 The "Strawman" concept has no basis in law in either the US or Canada - it is simply a myth. Nevertheless, the "Strawman" is a critical element of the US Sovereign Citizen movement and now has become integral to popular Canadian pseudolegal constructs.

Understanding and Intent and Claim of Right," online: Real Liberty Media <www.realliberty media.com/claim-of-right>; "Constructive Notice of Child of God Status," online: Scribd <www.scribd. $\mathrm{com} / \mathrm{doc} / 36023990 /$ constructive-notice-of-child-of-God-status>.

197 Menard, Bursting Bubbles, supra note 129 at 20-21.

198 Lindsay is the notable exception, and clearly is aware of the distinct legal traditions and jurisprudence.

199 Specifically: Menard, Clifford, Lindsay, Belanger, Gravenhorst, the TSILC/USN, Miller, Shrout, Fearn, Tellinger, Lentz, Laining, and the emerging gurus identified in $\mathrm{n} 236$, below.

200 Lindsay, Leave Application, supra note 125; David Kevin Lindsay, "Freedom! Is the Denial of Personhood!" DVD (CLEAR, 2010).

Phillips, supra note 15 at $11-17$.

This concept is so popular, it has spawned a 1950s newsreel style educational cartoon: Infomatic Films, "Meet Your Strawman!" (14 June 2010), online: Youtube <www.youtube.com/watch?v=ME7K6P7 hlko>. 
A full discussion of the various "Strawman" variations is beyond the scope of this article. What is important is that these schemes always include a backstory with certain critical elements:

1. Individuals are tricked into being associated with the "Strawman";

2. The "Strawman" is a necessary conduit for government and court authority;

3. The "Strawman" is a mechanism to take away natural or inherent rights;

4. The existence of the "Strawman" is skilfully concealed from the public but is nevertheless known to all judges, lawyers, politicians, and many other government and law enforcement authorities;

5. The "Strawman" can be unshackled or rejected, and to do so frees an individual from all government authority; and

6. With the "Strawman" removed, an individual is only subject to some other kind of law.

The "Strawman" concept is principally a mechanism to remove state authority, but it is also an integral component of the A4V money-for-nothing scheme. ${ }^{203}$ The powerful influence of the "Strawman" concept is illustrated by the fact that it persistently emerges even in contexts where it is entirely unnecessary. For example, a "no value provided" 204 foisted unilateral agreement debt evasion scheme does not require the involvement of the "Strawman" split/double person motif, but nevertheless it often appears. ${ }^{205}$ Similarly, the recent Fiscal Arbitrators tax evasion scam triggered undeserved tax refunds by claiming fictional business expenses - but those business expenses were generated, in theory, by transactions between the taxpayer and his "Strawman.",206

The appearance in Canada of the "Strawman" narrative marks a sharp change in the character of the OPCA phenomenon. Up to that point, OPCA litigation focused on legal loopholes or attacks on specific government taxing authorities. The "Strawman" necessarily requires a dramatic and negative reframing of the interrelationship between the citizen (slave) and the state (tyrant trickster). This plausibly has also meant a change in the kind of persons who are OPCA affiliates. The Detaxer era was arguably motivated by greed: pulling a fast one on the Taxman. That has potential appeal to practically any person. On the other hand, the modern OPCA phenomenon is a more dramatic and global rejection of the state,

203 Meads, supra note 4 at paras 531-43.

204 Thomas Bloy, "Pseudolaw and Debt Enforcement" (2013) March NZLJ 47; Rogozinsky, supra note 100 at paras 48-54.

205 Rogozinsky, ibid at paras 89-90, see also the attached documents from Laining's "Get Out Of Debt Free" website, supra note 184 .

206 See e.g. Janovsky $v$ R, 2013 TCC 140, [2013] 5 CTC 2004 [Janovsky]; Bhatti $v$ R, 2013 TCC 143 [2013] 4 CTC 2158 [Bhatti]; Bolduc v R, 2014 TCC 128, [2014] 6 CTC 2053; Torres v R, 2013 TCC 380, [2014] 2 CTC 2226, aff'd Strachan v R, 2015 FCA 60, [2015] 3 CTC 87; Chenard v The Queen, 2012 TCC 211, 2012 DTC 1195; Haynes v R, 2013 TCC 229, 2013 DTC 1186. To date, the underlying rationale for the Fiscal Arbitrators scheme has not been explained in any detail, though Janovsky at para 6 and Bhatti at para 13 indicate the double/split person motif and its "Strawman" are involved. 
legislature, courts, and other non-governmental institutions. This kind of belief has a more specialized social marketplace.

Similarly, the character of the guru has shifted from a quasi professional who shares special expertise ${ }^{207}$ to a prophet or revolutionary. Menard's narrative on how he discovered the deep, concealed secret of the "Strawman" deception illustrates the latter mode. Your Child Or Her Life! Deception and Evil in the Ministry of Children, Family and Community Development describes his revelatory moment of discovery:

I sat down with their Act and I had Black's Law dictionary on one side and Bouviers on the other. I looked up every single word. It took me three days. When I was done, I was stunned. I said one word "Sonofabitch". Some of their words do not mean what you think they do. They expand definitions and they use a great deal of deception. It is much like those laser engraved pictures which you can only see if you focus past the image. To see their deception you have to dig past layers of twisty words, but its there. ${ }^{208}$

This account is likely false. Menard most likely obtained his ideas from other US Sovereign Citizen and Canadian OPCA sources.

\section{B. THE OPCASPHERE}

Following the rise of the "Strawman," a kind of new, international pseudolegal tradition has emerged with accepted elements from many different sources, entwined with a matrix of false or distorted history and conspiratorial belief. This might be called the "OPCAsphere."

For a novice visitor, the Canadian OPCAsphere ${ }^{209}$ is a strange place. Its occupants see themselves surrounded by all manner of threats and conspiracies. They desperately search for uncontaminated sources of food and water. Aircraft contrails are scrutinized for evidence of government sponsored dissemination of chemicals. ${ }^{210}$ Spree shootings and terrorist incidents are "false flag" operations conducted by hidden hands to manipulate and control

Detaxer OPCA gurus claimed special knowledge in tax and law. This included use of experts in those fields, such as accountant Lovey Cridge ( $R v$ Lemieux, 2007 SKPC 135, [2008] 2 CTC 291) and former CRA employee Wally Dove (Maleki 401, supra note 93). Menard, Children, supra note 129 at 7-8.

While the Canadian OPCAsphere has surprising internal consistency, it is substantially different from the US Sovereign Citizen and Moorish Law variations. Each has its own conspiratorial and political focus, though all share the same ominous sense of impending tyranny and catastrophe. Harris, supra note 44, investigates the culture of the Sovereign Citizen OPCAsphere, and concludes that its ideas represent a desire for populist involvement in government processes by a predominately white and conservative population that is profoundly alienated from the modern multicultural character of the US. Its occupants seek a basis for their own authority to restore a perceived historical state with reduced government involvement and greater potential for self-determination. Harris sees this phenomenon as related to both a sense of marginalization and alienation, and populist conspiracy-based social perspectives by a community that is, curiously, not truly subordinated. Koniak, supra note 44, stresses how the Sovereign Citizen OPCAsphere is a second and distinct form of law, with its own perceived scheme, rules, and rights. See also Huhn, supra note 15. An interesting aspect of the US OPCA phenomenon is the ongoing existence of a less ideologically-oriented analogue to the now-extinct Canadian Detaxer movement. There are still OPCA promoters in that jurisdiction who advance discrete "tax loophole" strategies: see Harris, supra note 44 at 277-85; Danshera Cords, "Tax Protestors and Penalties: Ensuring Perceived Fairness and Mitigating Systemic Costs" (2005) 2005:6 BYUL Rev 1515 at 1531-43. See e.g. Peter Eric Hendrickson, Cracking the Code: The Fascinating Truth About Taxation in America (Hendrickson, 2003), online: Lost Horizons <losthorizons.com/Cracking the_Code.htm>.

210 These are "chemtrails," and are a popular subject in fringe conspiracy circles. The author often finds photos of aircraft contrails on OPCA-affiliated social media pages. 
the public. ${ }^{211}$ The OPCAsphere is permeated with impending threats, be it financial enslavement at the hands of "the Banksters," foreign or domestic military intervention, or ecological catastrophe. Police and government employees are nothing more than thugs. These apprehensions are closely linked to a sense of superiority - those who live in the OPCAsphere see themselves as possessing powerful, secret, or unusual knowledge, and that makes them very much better and smarter than the average person. Claims of courtroom success are met with excitement, though failure is not so often disclosed. Occupants promote their preferred guru and reinforce each other's conspiratorial beliefs by circulating and recirculating documents, videos, and "meme pictures." Those outside the OPCAsphere are dismissed; they are either enemy clients, paid government shills, or "sheeple."

Canadian forensic psychologists Jennifer Pytyck and Gary A. Chaimowitz ${ }^{212}$ investigated the mental health implications of OPCA affiliates' bizarre language and paranoid ideas. They concluded that the beliefs and consequential conduct of those in the OPCAsphere are not the product of a mental disorder but instead is a form of paranoid political belief: "extreme but subculturally-normative beliefs." ${ }^{213}$ Though they appeared psychotic, the authors concluded that the OPCA litigants' perspectives and actions were a consequence of honestly held ideas that have been reinforced in OPCA communities. OPCA litigants are therefore legally competent. Their incredible ideas and strange behaviors simulate the symptoms of psychosis, but are not amenable to treatment with antipsychotic medication. The authors stress the formulaic and bizarre manner in which OPCA affiliates' acts, use of language, and use of legal terminology mimics mental illness. ${ }^{214}$ Other academic commentators see parallels to religious cults. $^{215}$

The numerous internal inconsistencies in the OPCAsphere are a source of debate, ${ }^{216}$ but rarely in the context of actual jurisprudence and legislation. In many ways this collection of OPCA concepts has become a (pseudo)law unto itself. The preceding historical review demonstrates the largely conservative nature of OPCA litigation schemes. New schemes are rarely invented; most materials are recycled. The Hart 'gibberish' and " $\mathrm{n} / \mathrm{a}$ " income tax returns are a rare example of where an OPCA scheme has gone extinct and disappeared from the OPCAsphere.

211 Typically the perception is that these events are staged as a rationale for greater firearm control, or as a mechanism to negatively profile a group or interest.

212 Jennifer Pytyck \& Gary A Chaimowitz, "The Sovereign Citizen Movement and Fitness to Stand Trial" (2013) 12:2 Intl J Forensic Mental Health 149. The authors explain OPCA concepts using research about US sovereign citizens, but the broad penetration of these ideas into Canada means those resources are generally valid in this jurisdiction. The paper reports two case studies of individuals who expressed stereotypic OPCA concepts and were the subject of psychiatric assessment. See also George F Parker, "Competence to Stand Trial Evaluations of Sovereign Citizens: A Case Series and Primer of Odd Political and Legal Beliefs" (2014) 42:3 J American Academy Psychiatry \& L 338, which comes to the same conclusion for US Sovereign Citizens.

213 Pytyck \& Chaimowitz, ibid at 153.

214 A similar conclusion was drawn in Re JAG (2 May 2014), 2014 CanLII 32619 (Ont Consent and Capacity Board), online: < canlii.ca/t/gkbm> [JAG], but see Re NM, supra note 9 . The result in NM is arguably a consequence of the OPCA litigant having a diagnosed psychiatric condition prior to becoming an OPCA affiliate.

215 Stephen A Kent \& Robin D Willey, "Sects, Cults, and the Attack on Jurisprudence" (2013) 14:2 Rutgers JL \& Religion 306; Stephen A Kent, "Freemen, Sovereign Citizens, and the Challenge to Public Order in British Heritage Countries" (2015) 6 Intl J Cultic Studies 1.

216 A good example is the numerous alternative explanations of the double/split person "Strawman": Meads, supra note 4 at para 417. The existence of the mythical "Strawman" is, however, all but universally accepted. 


\section{COURT RESPONSE TO OPCA ARguments}

The conceptual and historical separation between the OPCAsphere and Canadian jurisprudence is starkly obvious in how courts respond to concepts that emerge from the deeper OPCAsphere narrative.

OPCA litigation arguments can be distinguished, in a somewhat oversimplified manner, as emerging from two different contexts: an individual legal error versus an elaborate alternative pseudolegal narrative. Certain OPCA arguments rely on a specific, discrete, and legally incorrect proposition. Examples include:

1. The Three or Five Letters ${ }^{217}$ foisted unilateral agreement scheme, which flows from the misconception that a contract offer may be accepted by silence;

2. The Detaxer division of powers argument, which is based on an incorrect interpretation of Nova Scotia (AG); ${ }^{218}$

3. The Detaxer argument that, since the Income Tax Act, ${ }^{219}$ section 248(1) definition of "person" "includes any corporation," it must therefore exclude any natural and physical flesh and blood persons; and

4. The CERI and Freeman argument that section 32 of the Charter restricts the application of all Canadian legislation to government actors.

OPCA arguments of this kind are amenable to detailed reasons and explanations. A specific legal issue can be extracted, analyzed, and rejected. Unsurprisingly, there are reported cases that do just that for each of these examples, respectively: Rogozinsky, ${ }^{220}$ Gauvreau, ${ }^{221}$ R. v. Lindsay, ${ }^{222}$ and Petrie. ${ }^{223}$

However, an analytical response is difficult when an OPCA argument emerges from the complex alternative world history and integrated pseudolaw of the OPCAsphere. Simply put, there is little common ground between that construct and established Canadian law. The "Strawman" is the perfect example. There is no possible reasoned judicial response to the "Strawman." It is simply false, and that is exactly what courts have said, time and again. ${ }^{224}$

This is a point that does not appear to have been recognized by legal academics. Jonnette Watson Hamilton and Alice Woolley in an 8 April 2013 blog post entitled "What has Meads

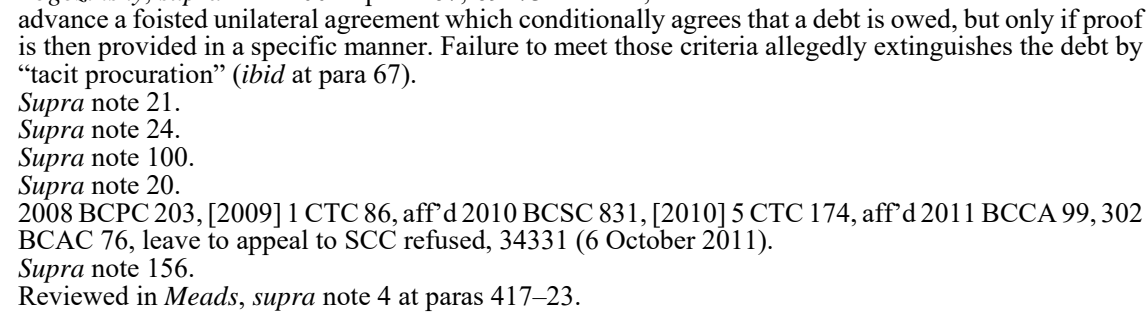
advance a foisted unilateral agreement which conditionally agrees that a debt is owed, but only if proof is then provided in a specific manner. Failure to meet those criteria allegedly extinguishes the debt by "tacit procuration" (ibid at para 67). Supra note 21.

Supra note 24.

Supra note 100.

Supra note 20.

2008 BCPC 203, [2009] 1 CTC 86, aff'd 2010 BCSC 831, [2010] 5 CTC 174, aff'd 2011 BCCA 99, 302

BCAC 76, leave to appeal to SCC refused, 34331 (6 October 2011).

Supra note 156.

Reviewed in Meads, supra note 4 at paras 417-23.

Rogozinsky, supra note 100 at paras 67,69-73. In brief, the Three/Five Letters scheme has a debtor 
v. Meads wrought?"225 identify certain post-Meads jurisprudence as providing an inadequate response to pseudolegal ideas advanced by OPCA litigants. Hamilton and Woolley direct particular criticism at the decision of Justice Campbell in Cassa v. The Queen, ${ }^{226}$ where the Court struck out an appeal of a Paradigm Education Group Detaxer who used the mature version of Porisky's natural person scheme which incorporates the "Strawman" concept. Hamilton and Woolley take particular exception to Justice Campbell's response ${ }^{227}$ to "Strawman" based strategies, and say this application of the Meads decision is:

a license to simply ignore what a litigant said.... A bare reference to Meads is put forward as a sufficient reason to ignore the arguments altogether. The same is true of Cassa, where Justice Campbell stated (at para 13): "My method of dealing with any attempt by the Appellant to employ this nonsense in my Court was to simply ignore it.",228

First, this analysis overlooks the substantive responses to OPCA arguments in Justice Campbell's decision. She:

1. Identifies elements that indicate Cassa is advancing a double/split person argument, ${ }^{229}$

2. Identifies elements of the Detaxer natural person scheme, ${ }^{230}$

3. Indicates Cassa has arbitrarily advanced legislation and model commercial law without indicating their relevance, ${ }^{231}$ and

4. Concludes the double or split person "Strawman" argument should be ignored because this alleged duality does not exist. ${ }^{232}$

Second, there is no possible legal response to the "Strawman"-based schemes other than to say this is nothing more than a spurious, illegitimate concept. Justice Campbell did that, and also indicated that this concept is reviewed and dismissed in Meads.

Jonnette Watson Hamilton \& Alice Woolley, "What has Meads v Meads wrought?" (8 April 2013) ABlawg (blog), online: <ablawg.ca/2013/04/08/what-has-meads-v-meads-wrought/>. 2013 TCC 43, 2013 DTC 1060 [Cassa].

In particular, see ibid at para 13:

Among many other such groups, the Meads decision identifies specifically the so-called "detaxers" or those attempting to avoid income tax obligations as well as the "freemen on land" notion and the double or split person concept. The Cassa appeal contains all of the foregoing elements. In the Further Amended Notice of Appeal, the Appellant refers to the "principal" as commonly called "Adrian of the Cassa family". In the Certificate of Service, he engages in the following similar language: "Comes, Adrian Cassa, as agent for the free will man, commonly called Adrian of the Cassa family, the undisclosed principal". Apparently, this is a common strategy in which such litigants engage. As the Meads decision notes, this duality argument is both a strange and confusing concept which uses an artificial and fictitious division of the person in an attempt to support an otherwise absurd argument. Whatever it is, it is without merit, it detracts from the court proceedings and it is total and utter nonsense. My method of dealing with any attempt by the Appellant to employ this nonsense in my Court was to simply ignore it.

Hamilton \& Woolley, supra note 225.

Cassa, supra note 226 at para 9.

Ibid.

Ibid at para 10

Ibid at para 13 . 
It is difficult to understand how a judge can respond otherwise where a litigant in court argues any variation of the "Strawman" scheme, particularly if that proceeding degenerates into a cat and mouse affair where the litigant claims to speak in two or more modes. ${ }^{233}$ The risk of doing otherwise is illustrated by the retrial of Detaxer Cameron Hardy, who successfully appealed a conviction for contempt of court on the basis that his guilty plea was made on behalf of his "Strawman" — but not by Hardy himself. ${ }^{234}$

The same issue emerges with certain other OPCA schemes that derive from the OPCAsphere's integrated matrix of conspiracy, false history, and pseudolaw. For example, there is no rational response to the $\mathrm{A} 4 \mathrm{~V}$ money-for-nothing scheme, and the courts have said as much: these ideas defy logic. ${ }^{235}$

\section{Conclusion}

The current OPCA community in Canada is highly fragmented despite the substantially common context provided via participation in the OPCAsphere. Many gurus ${ }^{236}$ compete for $^{\circ}$ the increasingly skeptical surviving customer base. This is less a lack of a consensus on the nature of the pseudolaw and the perceived illegitimacy (and immorality) of government than a search for tangible success. OPCA affiliates are confronted by many confounding factors: their gurus' promises have not been fulfilled; successes are, at best, rumour; OPCA affiliates are confronted by an increasing body of clear, carefully written rebuttals to their pseudolegal theories $;{ }^{237}$ and the public's response to the OPCA phenomenon has been overwhelmingly negative; they are "Freeloaders-on-the-Land." 238

OPCA ideas damage their adherents. A curious fact is that non-transitory OPCA affiliates are aware of this - they witness others fail and experience legal sanction. Why then do they persist? Pytyck and Chaimowitz explain this as a social phenomenon. ${ }^{239}$ OPCA concepts are propagated and consumed in marginal groups with extreme political and conspiratorial beliefs. Does this mean a dialogue with OPCA litigants is necessarily political, philosophical, or emotional, rather than based on fact, history, and logic?

Reviewed in Meads, supra note 4 at paras 440-44.

$R v$ Hardy, 2007 BCSC 125, 2007 BCSC 125 (CanLII), aff'd 2007 BCCA 523, [2008] 2 CTC 185.

Bossé, supra note 186 at para 42.

Domestic gurus Menard, Clifford, Lindsay, and Belanger remain active. Other Canadian OPCA promoters include: former Detaxer Wally Dove ("The Human Rights Defenders League in Canada," online: <humanrightsdefendersleague.ca $>$ ); alleged ex-lawyer "Marcus," Servant King, online: <www. servantking.info>; fake Notary Sino Cameron General (a.k.a. Chief Rock Sino General, Hajistahenthway) online: Facebook <www.facebook.com/groups/421863931237818/>; Mary Elizabeth Croft and an unidentified individual, "JD, Private Person," online: <private-person.com/>; see also Sue Wrongdoers, online: <suewrongdoers.com>; Marcel Bessette (actual name Marc Zurawell), "Peace Maker Society," online: <www.peacemakersociety.org>; "rob in the pagé family," online: $<$ consciousselfgovernance. ca/ $>$.

The OPCA community's response to this jurisprudence is interesting. There is little question that it is read and studied. Meads, supra note 4, for example, is obviously notorious. That said, in OPCA circles, it seems to be almost considered bad manners to raise the subject of these documents. There seems to be a pervading sense of embarrassment that no reasoned response has appeared to rebut these judgments. This phrase appears repeatedly in the comments added by the public to OPCA-related news stories, and also in the title of an article in The Economist: "Freeloaders on the land," The Economist (12 October 2013) 46.

Supra note 212 at 152-53. 
Sociologists Stephen Kent and Robin D. Willey group the OPCA phenomenon with religious cults. ${ }^{240}$ Both share a distance and disdain for government and court structures as a consequence of their beliefs. This ideologically-grounded hostility leads to both legal and extralegal efforts to pressure and exhaust government and court actors who are perceived as enemies. ${ }^{241}$ That makes these groups a security threat. ${ }^{242}$ Kent has subsequently concluded that although OPCA litigants "have no chance of receiving legal recognition" they are an important group for study because they are "profoundly alienated from society." 243 The result is not only a threat to government and court operation, but simply the waste of people's lives.

This perception of a dangerous separation in the world perspectives of residents of the OPCAsphere and the remainder of society is echoed by noted forensic psychologist and threat assessment expert J. Reid Meloy. He has identified the US Sovereign Citizens and Canadian Freemen-on-the-Land ideologies as a potential source for the last of three key elements that motivate ideologically driven violence in "lone wolf" terrorists: (1) personal grievance blamed on others, (2) moral outrage linked to a "victimized" group, (3) that is framed by a superficial, cherry-picked ideology which rationalizes aggression. ${ }^{244}$ Meloy explicitly groups OPCA ideologies with the beliefs of right wing hate groups and ultra conservative Islamic groups such as ISIS and Al Qaeda. Meloy is also a co-author of a recent Ontario study on the risks associated with offenders who have harassed justice system participants. ${ }^{245}$ A subset of that sample group were Freemen-on-the-Land. ${ }^{246}$

The gulf between the OPCAsphere narrative and mainstream Canadian perspectives and legal jurisprudence has another troubling implication. Unsuccessful OPCA litigants sometimes view their in-court failure not as clarification of the law, but rather conclude that the judges who have rejected their arguments are corrupt and have failed to uphold the true but concealed common law or natural law. As previously noted, there is little way for court or government actors to rebut what is, effectively, a faith-based belief in the "Strawman" and its associated conspiratorial, ahistorical narrative. Courts refuse attempts by OPCA litigants to enforce their beliefs via civil litigation against wrongdoers, including judges and lawyers. ${ }^{247}$ Will Canadian OPCA litigants then attempt to take "the law" into their own hands?

Ibid at 357-60.
Kent, supra note 215 at 12.

J Reid Meloy, "The Lone Terrorist in the Workplace," (16 December 2014), The Forensic Files (blog), online: Psychology Today <www.psychologytoday.com/blog/the-forensic-files/201412/the-loneterrorist-in-the-work place>. This article flows from the results of J Reid Meloy \& Jessica Yakeley, "The Violent True Believer as a "Lone Wolf" - Psychoanalytic Perspectives on Terrorism" (2014) 32:3 Behav Sci \& L 347. Harass Canadian Justice Officials" (2014) 1:3 J Threat Assessment \& Management 188.

The small Freeman fraction (4 of 86 ) of the study sample makes it difficult to draw any definitive conclusions, but it is interesting that this group showed a higher frequency of the approach behavior escalating risk factor: 50 percent versus 18 percent for the non-OPCA offenders: ibid at 196, 198. For example: Szoo', supra note 127; Rubbert v Boxrud, 2014 SKQB 221, 450 Sask R 147; Clifford, supra note 147; Clifford FC, supra note 147; Gratton, supra note 192; ANB, supra note 127; O'Brien $v$ Murchland, 2013 ONSC 4576, [2013] OJ No 3293 (QL); Viglione, supra note 188; Winningham v Canada (30 November 2010), Lethbridge 100600907 (Alta QB), leave to appeal to CA refused. 
The history of the OPCA phenomenon in Canada is therefore not merely a succession of unsuccessful pseudolegal ideas, but rather a broader evolution to a belief set and associated social group that is increasingly separated, and arguably alienated, from the general population. Bridging this gap will no doubt be a challenge, particularly as the leading voice against these ideas, the courts, are ill-suited to provide the kind of emotionally or perhaps philosophically based rebuttal that may be necessary. One can only hope that the kinds of anti-government activities that have emerged in the US Sovereign Citizen community ${ }^{248}$ are not repeated in Canada.

It seems that Canada has acted as something of an incubator for pseudolegal concepts which have now spread to other common law jurisdictions. Free-standing collections of Canadian OPCA concepts, particularly those of the Freemen-on-the-Land, have been transplanted to other countries including Australia, ${ }^{249}$ the UK, ${ }^{250}$ the Republic of Ireland, ${ }^{251}$ the Isle of Jersey, ${ }^{252}$ Scotland, ${ }^{253}$ Northern Ireland, ${ }^{254}$ and Norway. ${ }^{255}$ Given the apparent seductive appeal of these ideas, that list may very well further expand. It would be unfortunate if that were the case. Much of the public and judicial dialogue concerning the OPCA phenomenon has focused on the associated waste of public and court resources. In the author's opinion that concern is no more relevant than the terrible injury that is often caused to persons who attempt to use these schemes, such as incarceration, broken families, ${ }^{256}$ severe

Theret, supra note 15 at 868-79; Huhn, supra note 15 at $423-25$.

See e.g. Australian Competition \& Consumer Commission v Rana, [2008] FCA 374, [2008] ATPR 42223; Glew v The Governor of Western Australia, [2009] WASC 14, 222 FLR 417; Glew v White, [2012] WASC 100, aff'd [2012] WASCA 138, 2012 WL 2899731; Van den Hoorn v Ellis, [2010] QDC 451. Unlike most of the other affected jurisdictions, Australia has its own homegrown OPCA gurus and concepts, such as the UPMART organization, run by Malcolm McClure. See Freilich v Lambert, [2007] QDC 157, 2007 WL 2159682; Bob Jane Corporation Pty Ltd v Webtyre.net Pty Ltd, [2012] FCA 168, 2012 WL 866949; Harding v Deputy Commissioner of Taxation (No 2), [2008] FCA 1985; Rainima v Magistrate Freund, [2008] NSWSC 944, 2008 WL 4196630; Spajic v Robertson, [2007] NSWSC 553, 2007 WL 1578380; Frank O'Collins' UCADIA project, online: UCADIA <www.ucadia.com/>. See also ANB, supra note 127 at para 93.

250 See e.g. Doncaster Metropolitan Borough Council v Watson, [2011] EWHC B15, [2011] 3 FCR 422 (Fam); Re J, [2013] EWCA Civ 1685, [2014] 1 FCR 221. Debt elimination is the predominant focus of OPCA activities in the UK, with Mark "Ceylon" Laining of "Get Out Of Debt Free" having a leading role. Another influential figure in the UK is "Kate of Gaia," originally Canadian Keith Thompson. Thompson operates "Lose The Name," online: <losethename.com>, which claims government authority flows from its ownership of a person's name.

251 See e.g. Freeman $v$ Bank of Scotland (Ireland) Ltd, [2013] IEHC 371; Kearney v KBC Bank Ireland Plc, [2014] IEHC 260; McCarthy v Bank of Scotland Plc, [2014] IEHC 340; Harrold v Nua Mortgages Ltd., [2015] IEHC 15; Irish Bank Resolution Corporation Ltd v Peacock, [2015] IEHC 86; Tomás Keys, "Freeman on the Land and Other Organised Lay Litigant Groups - Part 1" (2014) 21:10 Commercial Law Practitioner 230; Tomás Keys, "Freeman on the Land and Other Organised Lay Litigant Groups - Part 2" (2014) 21:11 Commercial Law Practitioner 256. The Freeman seed has fallen on particularly fertile ground in Ireland where many individuals face foreclosure after the 2008/09 financial crisis. This has led to a populist OPCA political movement headed by Ben Gilroy, and a popular OPCA antiforeclosure scam, the "Rudolphus Allen Trust": see Reynolds v McDermott, [2014] IEHC 219. See Vibert v AG, [2013] JRC 030 (Jersey Royal Court).

253 See Watson v Lord Advocate, [2013] GWD 19-378, 2013 WL 2299936; Child Maintenance and Enforcement Commission v Wilson, [2013] CSIH 95, 2014 SLT 46.

254 Santander (UK) Plc v Parker, [2012] NICh 6; Santander UK Plc v Parker (No 2), [2012] NICh 20; Parker v McKenna, [2015] NIMaster 1.

255 Ingunn Røiseland appears to be the leading figure in this unexpected branch of the Freeman phenomenon, online: Tøvsugeren $<$ tovsugeren.blogspot.no/2013/05/konspirasjonsdronningen-som-ikkeville.html>; Humanist - Et tidsskrift for livssynsdebatt <www.skribler.no/2014/10/meg-eier-ingen/>. See e.g. AR v Alberta (Director of Child, Youth and Family Enhancement), 2013 ABQB 280, 562 AR 316; Curle v Curle, 2014 ONSC 1077, 2014 ONSC 1077 (CanLII); C(MD) v C(T), 2012 NBQB 376, 2012 NBBR 376; Penney v Tufts, 2014 NSCA 38, 343 NSR (2d) 378; H(S) v J(G), 2013 BCPC 242, 2013 BCPC 242 (CanLII); C (C), supra note 9; Re S(A), 2014 ABPC 300, 2014 ABPC 300 (CanLII). 
financial injury, ${ }^{257}$ psychiatric detention, ${ }^{258}$ and the loss of homes. ${ }^{259}$ This more personal consequence of OPCA litigation is another reason why this subject deserves study, and if possible, effective response. R 15, aff'd 2014 SKCA 127, 2014 SKCA 127 (CanLII). were unsuccessfully advanced in response to home foreclosures or evictions: Canadian Western Trust Company v Bidea, Wetaskiwin 1201-01993 (Alta QB); Alberta Treasury Branches v Nielson, 2014 ABQB 383, 14 CBR (6th) 177; Re Reynolds Estate, Edmonton ES03 116011 (Alta QB); Bank of Nova Scotia v Pink Ice Limo's \& Charters Ltd, Edmonton 120302897 (Alta QB); Bank of Nova Scotia v Harris, Edmonton 120308198 (Alta QB); Manulife Bank of Canada v Chorney, Edmonton 130313861 (Alta QB). 